This is the author's version of a work that was accepted for publication in the Journal, Corrosion Science. Changes resulting from the publishing process, such as peer review, editing, corrections, structural formatting and other quality control mechanisms may not be reflected in this document. Changes may have been made to this work since it was submitted for publication. A definitive version was subsequently published in the Journal, Corrosion Science, Volume 79, February 2014, Pages 89-99. http://doi.org/10.1016/j.corsci.2013.10.030 


\section{Accepted Manuscript}

Filtration-UV irradiation as an option for mitigating the risk of microbiologically influenced corrosion of subsea construction alloys in seawater

Laura L. Machuca, Robert Jeffrey, Stuart I. Bailey, Rolf Gubner, Elizabeth L.J. Watkin, Maneesha P. Ginige, Anna H. Kaksonen, Krista Heidersbach

PII: S0010-938X(13)00460-5

DOI: http://dx.doi.org/10.1016/j.corsci.2013.10.030

Reference: CS 5577

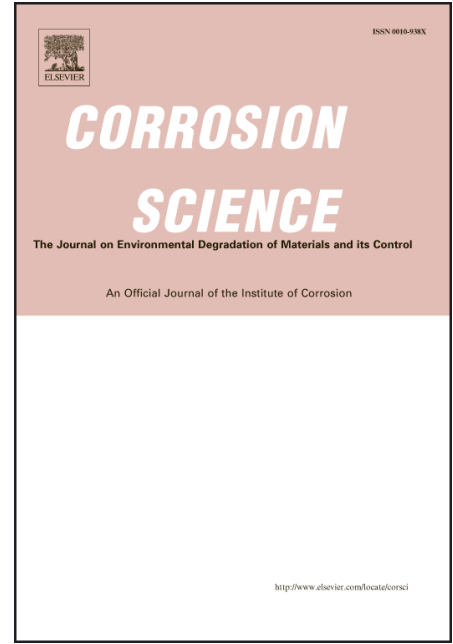

To appear in:

\section{Corrosion Science}

Received Date:

19 June 2013

Accepted Date:

26 October 2013

Please cite this article as: L.L. Machuca, R. Jeffrey, S.I. Bailey, R. Gubner, E.L.J. Watkin, M.P. Ginige, A.H. Kaksonen, K. Heidersbach, Filtration-UV irradiation as an option for mitigating the risk of microbiologically influenced corrosion of subsea construction alloys in seawater, Corrosion Science (2013), doi: http://dx.doi.org/ 10.1016/j.corsci.2013.10.030

This is a PDF file of an unedited manuscript that has been accepted for publication. As a service to our customers we are providing this early version of the manuscript. The manuscript will undergo copyediting, typesetting, and review of the resulting proof before it is published in its final form. Please note that during the production process errors may be discovered which could affect the content, and all legal disclaimers that apply to the journal pertain. 


\title{
Filtration-UV irradiation as an option for mitigating the risk of microbiologically influenced corrosion of subsea construction alloys in seawater
}

\author{
Laura L. Machuca ${ }^{a^{*}}$, Robert Jeffrey ${ }^{\mathrm{b}}$, Stuart I. Bailey ${ }^{\mathrm{a}}$, Rolf Gubner ${ }^{\mathrm{a}}$,Elizabeth L.J. Watkin ${ }^{\mathrm{a}, \mathrm{c}}$ \\ Maneesha P. Ginige $^{d}$, Anna H. Kaksonen ${ }^{d}$, Krista Heidersbach ${ }^{\mathrm{e}}$ \\ ${ }^{\mathrm{a}}$ Corrosion Center for Education, Research and Technology Corr-CERT, Curtin University, \\ Technology Park, Bentley, WA 6102 \\ ${ }^{\mathrm{b}}$ Centre for Infrastructure Performance and Reliability, The University of Newcastle, NSW 2308, Australia \\ ${ }^{\mathrm{c}}$ School of Biomedical Sciences, Curtin University, Bentley WA 6102, Australia. \\ ${ }^{\mathrm{d}}$ CSIRO Land and Water, Private Bag No. 5, Wembley WA 6913, Australia. \\ ${ }^{\mathrm{e}}$ Chevron Energy Technology Company, Houston, TX 77002 \\ * Corresponding author. Tel: + 61 425428809; Fax: + 61892667221. \\ E-mail address: 1.machuca2@curtin.edu.au
}

\begin{abstract}
The effect of filtration-UV irradiation of seawater on the biofilm activity on several offshore structural alloys was evaluated in a continuous flow system over 90 days. Biofilms ennobled the electrode potential by $+400-500 \mathrm{mV}$ within a few days of exposure to raw untreated seawater. Filtration-UV irradiation of the seawater delayed the ennoblement of the steels for up to 40 days and lowered localized corrosion rates in susceptible alloys. Ennobling biofilms were composed of microbial cells, diatoms and extracellular polymeric substances and the bacterial community in biofilms was affected by both the alloy composition and seawater treatment.
\end{abstract}

Keywords: steel, alloy, SEM, microbiological corrosion, pitting corrosion. 


\section{Introduction}

Virtually any metal surface exposed to water is susceptible to microbial colonization and biofilm formation. Biofilms are sessile communities of microbial cells and extracellular products associated with a substratum [1-3]. Biofilms seem to be a preferential mode of life for microorganisms as it offers a more sustainable environment for their survival, growth and reproduction [4-6]. In addition, biofilm development allows mutualistic and synergistic interactions between microorganisms and affords protection from external harsh conditions [5,7]. Within these biofilms, microorganisms can initiate, facilitate or accelerate metal corrosion reactions in a phenomenon known as microbiologically influenced corrosion (MIC) [8-10].

In the construction of subsea pipelines, carbon steel has been the dominant metallic material since it has tremendous advantages of a large experience base and strong technical background along with moderate cost. However, corrosion resistant alloys such as stainless steels and nickel-based alloys are becoming more important structural materials due to their combination of high strength and resistance to corrosion in aggressive offshore environments. Corrosion resistant alloys suffer negligible general corrosion in seawater due to a protective, predominantly chromium oxide, film that forms immediately on the surface with exposure to air $[11,12]$. However, these alloys do still suffer localised corrosion in seawater, i.e. pitting corrosion, crevice corrosion, stress corrosion cracking (SCC) and microbiologically influenced corrosion (MIC) [13-16].

Microorganisms do not produce a unique type of corrosion but rather they influence or shift the existing mechanisms for corrosion. Most studies report MIC as a mode of localized corrosion [17-19]. Previous studies on MIC have postulated several mechanisms through which microorganisms can aggravate localized corrosion on active-passive alloys. It has long been known that natural biofilms are able to shift the $E_{c o r r}$ of active-passive alloys in the noble direction, a phenomenon collectively known as ennoblement. Ennoblement has been widely studied and numerous reports from geographically diverse sites have been published over the years [20-24]. The significance of this phenomenon lies in its influence on the susceptibility to corrosion of anode materials in galvanic couples and the initiation and propagation of localized corrosion [25, 26]. Other MIC mechanisms include biodeposit formation leading to a crevice type of attack [15], acceleration of propagation rates for crevice corrosion and decrease of the critical potentials for pitting and crevice corrosion initiation $[14,27]$.

The use of natural seawater in the hydrotesting of subsea pipelines prior to commissioning is becoming an issue of increasing importance to the oil and gas industry. This practice can contaminate 
the internal surface with microorganisms, sand and salts, even after the water has been removed, increasing the possibility of internal localized corrosion, particularly MIC [28-30]. Therefore, hydrotest seawater must be properly treated in order to reduce the possibility of contamination and severe corrosion damage and to prolong pipeline and equipment service life [31, 32].

Generally, the risk of MIC can be minimized by using chemical biocides to control the growth of suspended cells and further biofilm formation on steels [33, 34]. However, environmental concerns associated with chemical disinfection and biocide disposal have led to the consideration of physical methods for treatment of industrial waters. Furthermore, factors such as chemical incompatibilities, persistence, toxicity, cost and degradation associated with the use of chemical biocides are becoming an issue of increasing importance to the oil and gas industry. Filtration and ultraviolet (UV) light disinfection can be a good supplementary method to traditional chemical treatments for management of industrial waters as it can greatly reduce the amount of chemical biocides required for water disinfection. Filtration and settlement reduce the amount of sediments, larger organisms and nonsoluble organic matter which increases the UV light disinfection capacity. UV radiation damages proteins and membranes and indirectly damages DNA by creating reactive oxygen compounds (e.g., $\mathrm{H}_{2} \mathrm{O}_{2}, \mathrm{O}_{2}^{-}$etc.) causing single-strand breaks in DNA which ultimately leads to the death of the microorganisms [35].

In this study, several offshore construction alloys were exposed to slowly flowing natural seawater that ensured a constant loading rate of nutrients and promoted the formation of mature and active biofilms in a test rig established in New South Wales, Australia [36]. The particular design of the test rig allowed for the evaluation of the alloys corrosion performance in raw untreated seawater as well as filtered-UV irradiated seawater. The corrosion performance of the alloys was investigated by monitoring corrosion potential over time and conducting surface analyses. Bacterial diversity in biofilms formed on the different alloys in raw and treated seawater was examined by polymerase chain reaction (PCR) of bacterial 16S rRNA gene fragments followed by denaturing gradient gel electrophoresis (DGGE). Molecular characterization of biofilm communities has become crucial to understand the complexity of the interactions of biofilms with substratum surfaces and the surrounding environment [16, 37-41]. The sensitivity of this technique allowed an assessment of the degree to which exposure conditions and material composition affect the bacterial community and shift the diversity in the biofilms. 


\section{Experimental details}

\subsection{Specimen preparation}

Commercial carbon steel, stainless steels UNS S31603, UNS S31803, UNS S32750, UNS S31254 and the nickel-base alloys UNS N08825 and UNS N06625 were used in this study. The chemical composition of the alloys in weight per cent is presented in Table 1. Square coupons (20 mm x $20 \mathrm{~mm}$ $\mathrm{x} 5 \mathrm{~mm}$ thick) were cut from the supplied plate samples and a $2 \mathrm{~mm}$ diameter hole was drilled in one corner. An electrical connection was established via a copper wire soldered to one side of the coupon. To prevent crevice corrosion, samples were electrocoated with a protective epoxy (Powercron ${ }^{\circledR}$ 6000CX, PPG Industrial coatings) at the surface area where the spot weld was made for electrical connection and uncovered weld areas further covered by epoxy resin (Belzona 1391, Belzona polymerics Ltd.). Prior to exposure, coupons were wet ground to a 600 grit finish, soaked in Decon ${ }^{\circledR}$ 90 (Decon laboratories Limited) for 3 hours and sterilized by immersion in 70\% ethanol for 1 hour. Coupons were finally dried with nitrogen, weighed in triplicate and total coupon areas were measured using a digital gauge. Coupons were suspended by nylon strings in the experimental tanks.

\subsection{Test conditions}

Two lots of triplicate coupons of each material were exposed to streams of continuous low velocity $\left(<1 \mathrm{~mm} \mathrm{~s}^{-1}\right)$ natural coastal seawater in a test rig established in a field laboratory within the Port Stephens Fisheries Centre site at Taylors Beach, New South Wales, Australia. A detailed description of the experimental rig is given elsewhere [36]. One stream was untreated and passed straight into a sealed 2001 experimental tank (referred to as raw seawater). A second stream was pumped into settling tanks followed by a series of filters down to $5 \mu \mathrm{m}$, passed over ultra violet lamps in tandem before going into another sealed $200 \mathrm{~L}$ experimental tank. This tank was continuously irradiated with ultraviolet (UV) light (lamp placed above water) in order to kill microorganisms without changing the chemical properties of the water (referred to as treated seawater). The UV lamps used were 40 Watt input UV-C light lamps (254 nm wavelength). UV-C irradiation has been shown to be very effective in controlling marine biofouling development [42]. Lamps were checked daily.

The chemical composition of the seawater is shown in Table 2. Water temperatures in the experimental tanks were recorded daily for the duration of the experiment (Tinytag Aquatic, Gemini Data Loggers, UK). 


\subsection{Electrochemical studies and determination of corrosion rates}

The corrosion potential $\left(E_{c o r r}\right)$ of each electrode was measured against a type CCS1-PORT Ag/AgCl portable seawater reference electrode (Silvion Limited, accuracy Vs SCE in $3 \% \mathrm{NaCl}$ at $20^{\circ} \mathrm{C}:-5 \mathrm{mV}$ $+/-5 \mathrm{mV}$ ) and recorded every four hours using a multichannel data logger (dataTaker DT605, dataTaker Pty Ltd). Coupons were withdrawn after 90 days immersion, cleaned following the standard procedure [43] and weighed in triplicate to calculate weight loss and corrosion rates of each sample [43]. The average corrosion rate over the 3 month exposure is calculated according to the following equation (Eq. (1)):

? $=k$ ? $/ \rho A t$,

where $?=$ corrosion rate, $\mathrm{mm} \mathrm{y}^{-1} ; k=$ constant, $8.76 \times 10^{4}$; ?=weight loss, g;

$\rho=$ density, $\mathrm{g} \mathrm{cm}^{-3} ; A=$ area in $\mathrm{cm}^{2} ; t=$ time of exposure in $\mathrm{h}$.

In calculating an average, it is not specifically implied that the corrosion rate remains constant for this time. Neither is it implied that this corrosion rate will be sustained for periods of years, but rather the measured corrosion is presented in units of $\mathrm{mm} \mathrm{y}^{-1}$ for the purpose of comparison with well recognized values in this unit. One-way analysis of variance (ANOVA) was conducted to examine the significance of variations in corrosion rates between treated and untreated seawater coupons of the same type at a significance level of 0.05 (calculated as statistical $p$ values).

\subsection{Evaluation of biofilm formation by SEM}

Natural marine biofilms formed on the coupons exposed to coastal seawater under freely corroding conditions were examined by scanning electron microscopy (SEM). After 90 days exposure, biofilmcoated coupons were removed from experimental tanks and fixed in glutaraldehyde $(2.5 \%$ in $0.025 \mathrm{M}$ phosphate buffered saline (PBS) (Sigma), pH 7.4) containing 0.15\% w/v Alcian Blue (Sigma Aldrich) and incubated at room temperature for a minimum of $22 \mathrm{~h}$. Coupons were then washed with PBS $(0.025 \mathrm{M}, \mathrm{pH}$ 7.4) and fixed in sterile $1 \%$ osmium tetroxide for $30 \mathrm{~min}$. Coupons were then dehydrated through a graded series of ethanol (15 min each): 50, 75, 90 and 100\% dry ethanol successively. Dehydrated coupons were critical-point dried (CPD) in liquid carbon dioxide using an E3000 Critical Point Dryer (Quorum Technologies). After CPD, coupons were sputter-coated with 
platinum (5 nm thickness) using a SC7640 Sputter Coater, Quorum Technologies. SEM imaging was performed on a Zeiss 1555 VP-FESEM using an in-lens detector with a $30 \mathrm{~mm}$ aperture, accelerating voltage of $3 \mathrm{kV}$ and a working distance of 4 to $5 \mathrm{~mm}$.

\subsection{Optical surface analysis for corrosion evaluation}

Localized corrosion of the alloys was evaluated by surface optical measurements using an infinite focus microscope (IFM G4g system, Alicona Imaging). One-way analysis of variance (ANOVA) was conducted to examine the significance of variations in pit depths and pit density analyses between treated and untreated seawater coupons of the same type at a significance level of 0.05 (calculated as statistical $p$ values).

\subsection{Analysis of bacterial diversity by PCR-DGGE}

The diversity in the biofilm communities developed on the test alloys exposed to raw and treated seawater was examined by PCR-DGGE analysis. Applying this method, different DNA sequences from individual bacterial species in a biofilm community can be separated based on differences in their melting behavior on a denaturing gradient gel [41]. By comparing the melting behavior, or the positioning of the DNA bands, side-by-side on the gel, it is possible to detect differences in biofilm community composition and diversity.

At the completion of the 90 days exposure period, duplicate coupons of each material were removed from the experimental tanks and resuspended separately in small vials containing sterile seawater and $0.1 \%$ (w/v) Tween 20. Microbial cells were detached by 60 second-sonication steps (solution was refreshed between sonication steps) until no microbial cells were observed in the solution under a phase contrast microscope. For each material, suspensions from all sonication steps were filtered through $0.2 \mu \mathrm{m}$ pore diameter polycarbonate membrane filters (IsoporeTM, Millipore Corp.) and DNA from microorganisms on the membrane filters was extracted using a DNA extraction kit (PowerSoil $^{\mathrm{TM}}$ DNA Isolation Kit, MO BIO Laboratories Inc). DNA was used as template to amplify a specific region of the bacterial 16S rRNA gene using nested PCR approach. The outer primer pair was $27 \mathrm{~F}$ and $1492 \mathrm{R}$ and the inner primer pair was 357F-GC and 907R (Table 3) [44, 45]. The PCRamplified 16S rRNA gene fragments from different species were separated by DGGE using a DCode Universal Mutation Detection System (BIORAD) as per the manufacturer's instructions. The PCR products were mixed with DNA loading buffer (BIOLINE) and loaded into 7\% (w/v) polyacrylamide gel (40\% acrylamide/bis solution, 37.5:1) with a denaturing gradient of 30-60\% urea-formamide (100\% denaturant: $7 \mathrm{M}$ urea, $40 \%$ deionised formamide) in 1x TAE buffer (2 M Tris base, $1 \mathrm{M}$ glacial acetic acid, $50 \mathrm{mM}$, EDTA, pH 8.0). The DGGE was run at $150 \mathrm{~V}$ at $60^{\circ} \mathrm{C}$ for 16 hours. DNA bands 
were visualized using a gel illuminator following staining with SYBR® Gold nucleic acid gel stain (Invitrogen ${ }^{\mathrm{TM}}$ ).

More detailed analyses of individual biofilm populations, such as DNA sequencing and speciation, are beyond the scope of the present study.

\section{Results}

\subsection{Corrosion Potential}

Figure 1 shows average $E_{c o r r}$ evolution in time of the test materials exposed to raw and treated seawater for 90 days. For all the corrosion resistant alloys exposed to raw seawater (Figure 1 [a-f]) $E_{c o r r}$ shifted from negative to positive values during the first 5 days of exposure. For most of the alloys, $E_{\text {corr }}$ continued to increase with time and only minor active-passive states were observed over the exposure period. For UNS S31603 (Figure 1[a]), large active-passive peaks were more evident during exposure as compared with the other alloys. For most of the alloys, these active peaks were detected after 20-30 days exposure to raw seawater except for UNS N08825 (Figure 1[f]) where a drastic shift of $E_{\text {corr }}$ towards active values was observed after a maximum ennoblement had been attained during the first 5 days of exposure. $E_{c o r r}$ of all alloys exhibited a clear tendency to ennoble with exposure. Corrosion resistant alloys exposed to filtered-UV treated seawater displayed a fairly stable $E_{c o r r}$ during the first 40 days of exposure with a slight trend towards negative values with time. It can be seen that after 40 days exposure, $E_{c o r r}$ of all alloys exposed to treated seawater shifted to electropositive values and increased gradually with exposure. After this initial ennoblement, $E_{\text {corr }}$ of some of the alloys exposed to treated seawater displayed active-passive transition peaks. In all alloys, $E_{\text {corr }}$ ennobled approximately $+400-500 \mathrm{mV}$ relative to the initial $E_{\text {corr. }}$. The maximum ennoblement attained during exposure was slightly higher for alloys exposed to raw seawater compared to alloys exposed to treated seawater although values were comparable. $E_{\text {corr }}$ of carbon steel exposed to raw seawater (Figure $1[\mathrm{~g}]$ ) slightly decreased during the first 5 days exposure and then displayed a smooth tendency towards more positive values with time. $E_{\text {corr }}$ of carbon steel was ennobled about $+50 \mathrm{mV}$ relative to the initial $E_{\text {corr }} E_{\text {corr }}$ of carbon steel exposed to treated seawater also showed a slight increase over time although the material did not show considerable ennoblement. 


\subsection{Temperature}

The exposure temperature in the experimental tanks measured over the course of the immersion period is plotted in Figure 2. Initial exposure temperatures were about $18-19^{\circ} \mathrm{C}$ and reached maximum values of $\sim 28^{\circ} \mathrm{C}$ after 30 days of exposure. Average temperatures were $23.1^{\circ} \mathrm{C}$ and $22.7^{\circ} \mathrm{C}$ for treated and raw seawater tanks, respectively. The slight increase in temperatures in the treated seawater tank is attributed to the effect of UV lamps.

\subsection{Corrosion rates}

Average corrosion rates calculated from weight loss of test materials are shown in Figure 3. Corrosion rates of high corrosion resistant alloys (Figure 3[a]) were very low in both in raw and treated seawater (displayed in $\mu \mathrm{m} \mathrm{y}^{-1}$ ). UNS N08825 exhibited the highest corrosion rates between the high corrosion resistant alloys in both raw and treated seawater $\left(\sim 0.3 \mu \mathrm{m} \mathrm{y}^{-1}\right)$ and UNS N06625 showed the lowest corrosion rates between these alloys $\left(\sim 0.05 \mu \mathrm{m} \mathrm{y}^{-1}\right)$.

Carbon steel (Figure 3[b]) displayed corrosion rates of $\sim 0.12 \mathrm{~mm} \mathrm{y}^{-1}$. There was not significant variation in the corrosion rate of alloys exposed to treated and untreated seawater (UNS S31603: $p=$ 0.37; UNS S31803: $p=0.40$; UNS S32750: $p=0.40$; UNS S31254 $p=0.39$; UNS N6625: $p=0.10$; UNS N8825: $p=0.52$; Carbon steel: $p=0.28$ ).

\subsection{Surface analysis}

Surface analysis by optical microscopy was conducted at the completion of the exposure to evaluate localized corrosion. Carbon steel showed severe localized corrosion (Figure 4) and the extent of the attack was higher in the raw seawater than in the treated seawater. For carbon steel, pit densities could not be measured due to the nature of the attack. Carbon steel exposed to raw seawater was severely attacked on the corners (Figure 4[a]) whilst random localized attack throughout the surface was observed in carbon steel exposed to treated seawater (Figure 4[b]). Carbon steel exposed to raw seawater exhibited significantly higher maximum depths of attack (500 $\mu \mathrm{m}$ at the corners) than carbon steel in treated seawater $(50 \mu \mathrm{m})(p=<0.05)$.

Figure 5 shows the pitting analysis (pit density and pit depths) for the corrosion resistant alloys studied. Pitting corrosion was observed on the alloys UNS S31603 and UNS N08825 exposed to raw and treated seawater and was not detected on UNS S32750, UNS S31254 and UNS N06625. UNS N08825 exhibited the highest pit density as well as the highest average and maximum pit depths in both raw and treated seawater. A few shallow pits (less than $10 \mu \mathrm{m}$ depth) were found on UNS S31803 exposed to both raw and treated seawater. UNS S31603 and UNS N08825 exposed to raw 
untreated seawater exhibited significantly higher pit density and maximum pit depths than treated seawater coupons $(p=<0.05)$. In contrast, there was not significant variation in pit density $(p=0.22)$ and maximum pit depths $(p=0.13)$ between UNS S31803 exposed to treated seawater and UNS S31803 in raw untreated seawater.

Grain structures were evident on a small region of the surface of UNS S31603 exposed to raw seawater and intergranular corrosion (IGC) was apparent (Figure 6). No evidence of intergranular corrosion (IGC) was found on UNS S31603 exposed to filtered-UV treated seawater.

\subsection{Biofilm imaging}

SEM images of biofilms developed on the test alloys after 90 days exposure to seawater are shown in Figure 7. Biofilms were observed on coupons exposed to raw seawater as well as treated seawater. From SEM imaging, there were no noticeable differences in physical structure between biofilms formed in raw and treated seawater. However, the pattern of colonization and biofilm structure differed between materials. Ennobling biofilms on corrosion resistant alloys consisted of microbial cells, diatoms and extracellular polymeric substance (EPS) in both treated and raw seawater (Figure $7[a])$. However, diatoms were much less abundant in biofilms formed on alloys exposed to treated seawater than raw seawater.

Biofilms on UNS S31603 (high pit density) were thin and irregular along the surface forming net-like structures and patchy deposits and aggregates (Figure $7[\mathrm{~b}]$ ). The alloy surface was not fully covered by biofilms. Biofilms formed on UNS S31803 (shallow pits), UNS S32750 and UNS S31254 (not pitted) partially covered the surface and were thicker and more complex than those formed on UNS S31603 (Figure 7[c]). Biofilms developed on the nickel based alloys UNS N08825 (high pit density and pit depths) and UNS N06625 (not pitted) were indistinguishable between the two alloys. These biofilms were very dense with microbial cells, filamentous structures and diatoms embedded in copious amounts of EPS and fine overlapping material on the entire surface (Figure 7[d]). This fusing material appeared as a connecting structure among biofilm components. These biofilms were most often aggregated into high and irregular structures. On the other hand, carbon steel surfaces show individual microbial cells and aggregates encrusted with corrosion products over the entire surface in both treated and raw seawater tests (Figure $7[\mathrm{e}]$ ). There was no correlation found between biofilm thickness and the extent of pitting corrosion on the different materials.

\subsection{PCR-DGGE analysis of bacterial diversity}

PCR-DGGE analysis of biofilms revealed a shift in bacterial community in biofilms as a function of substratum material (Figure 8). Bacterial DNA was extracted from all the materials exposed to both treated and raw seawater. The individual bands seen in each lane of the DGGE are related to the 
predominant bacterial populations present in each biofilm formed on the different materials and the number of bands gives an indication of the bacterial diversity in biofilms. DGGE analysis indicated that for each type of material the number and types (indicated by the melting behaviour and positioning of the band in the gel) of bacterial populations in biofilms formed in raw seawater differed from those formed in treated seawater (encircled bands for each material in Figure 8). However, for each material certain bacterial species were part of both the biofilm community developed on the raw seawater and the one developed on the treated seawater (DNA bands from raw and treated seawater biofilms showing the same positioning on the gel). Likewise, several bacterial species were commonly encountered in biofilms developed on different materials although some species were only found in biofilms grown on certain materials but not on others. No obvious decrease in DGGE band numbers in the treated seawater was observed compared to the raw seawater. UNS N08825, UNS S31603 and UNS S31803 exhibited the highest microbial diversity ( 8 to 10 bands) between the different materials.

\section{Discussion}

The use of preservation treatments for industrial waters is a crucial practice to provide protection of subsea pipelines against MIC. Issues surrounding the use of chemical biocides to control biofilm growth on internal surfaces of offshore structural alloys have led to the interest in alternative seawater treatments for mitigating biofilm growth and preventing MIC. In this work, the influence of filtrationUV irradiation on the control of biofilm growth and activity on several alloys and finally on MIC in seawater was investigated. As it has been demonstrated in previous studies, results from this work indicate that microorganisms can rapidly colonize the steel surfaces immersed in natural seawater and ennoble their $E_{\text {corr }}$. The extent of the ennoblement observed in these experiments was similar to values reported by researchers in other geographical regions [20, 46, 47]. Previous studies on the phenomenon of ennoblement have indicated that the rapid ennoblement of $E_{c o r r}$ of steels in natural waters is directly associated with the formation of a biofilm on the surface following exposure. Hence, it can be inferred from the present study that filtration-UV radiation was effective in delaying biofilm formation and consequently ennoblement of the alloys corrosion potential for up to 40 days. The drastic $E_{\text {corr }}$ ennoblement observed simultaneously on all test alloys after the 40-day exposure to treated seawater could be due to a temporary failure of the UV system likely during off-working hours when the test rig can be unattended. Under these conditions, new seawater microorganisms introduced into the experimental tank can colonize the alloys surface within a few hours of exposure and rapidly form a biofilm matrix. Once a biofilm is established, microbial cells can be sheltered by exopolymeric substances, allowing an apparent increased UV resistance [48]. The above assumption is consistent with the persistence of the ennoblement observed on the alloys exposed to the UV treated seawater from the day 40 until the end of the exposure period. The biofilm formation on alloys exposed to both 
treated and raw seawater was confirmed by SEM imaging. However, since time-course studies of biofilm formation were not performed (only a single-point measurement was conducted at the end of exposure) it is not possible to determine when exactly a biofilm was formed on the alloys surface. Nevertheless, It is commonly reported that initiation of ennoblement is directly related to microbial colonization and biofilm growth on the steel surface [49].

Several mechanisms have been proposed to explain the phenomenon of ennoblement but unifying mechanisms for global observations have not been identified. Numerous researchers have shown that increased cathodic reduction rates accompany ennoblement of $E_{\text {corr }}[20,50]$. In marine waters, this has been attributed to organometallic catalysis [51], acidification of the metal surface [52], catalysis by bacterially produced enzymes [23, 24], the combined effects of low $\mathrm{pH}$ and production of hydrogen peroxide within biofilms [52] and microbially produced inhibitors [53]. More recently, it has been demonstrated that certain bacteria are able to switch from natural soluble electron acceptors and donors to solid electrodes so that there is a direct transfer of electrons between bacterial cells and conductive surfaces. Direct microbial electron extraction from solid electrodes has shown to be induced by carbon starvation [19]. In the absence of a soluble organic electron donor some bacteria can develop electron transfer capability where the solid electrode serves as the only electron donor to support growth without the need for soluble electron mediators. Under these conditions bacteria have shown to catalyse the cathodic reactions and ennoble the electrode potential [54, 55]. This direct electron uptake mechanism seems to be mediated by membrane bound electron proteins such as c-type cytochromes and bacterial nanowires that transfer electrons from outside the cells to the cytoplasm and vice versa. The enhanced cathodic reaction by microbial direct electron transport is thought to be less sensitive to mass-transfer compared to reactions using oxygen or other soluble species. This is because mass transfer resistance within biofilms can limit the diffusion of soluble cathodic reactants from the bulk solution to the metal surface thus hindering the corrosion reaction.

Ennoblement has also been related to the settlement of living sea diatoms on stainless steels [20]. It was suggested that ennoblement was caused not by the metabolism but by the metabolite of the sea diatoms contained in a thin organic film adhered to the steel. In the present study, sea diatoms were found embedded in the EPS of ennobling biofilms on the different alloys which may suggest they could have played a role in the observed ennoblement. It is probable that all of these mechanisms, either singly or in combination, may contribute to the ennoblement of the alloys. However, the precise mechanisms of ennoblement by biofilms on the selected corrosion resistant alloys were not investigated in this work.

Surface analysis indicated that localized corrosion occurred on carbon steel and on the corrosion resistant alloys UNS S31603, UNS N08825 and UNS S31803 exposed to both raw and treated seawater. Localized corrosion was not detected on UNS S32750, UNS S31254 and UNS N06625 
despite the large ennoblement of $E_{\text {corr }}$ attained by these alloys during exposure. Similarly, no correlation was found between $E_{\text {corr }}$ values and the uniform corrosion rates observed on all selected alloys in seawater. Corrosion rates by weight loss of corrosion resistant alloys in seawater did not give a direct indication of their pitting corrosion susceptibility in seawater. These findings highlight that for corrosion assessment, weight loss measurements are only appropriate for indicating the uniform corrosion tendency of alloys at particular environments. The results are difficult to interpret in the presence of localized corrosion such as pitting, the most frequent form of attack found in passive alloys in chloride environments. Under these conditions, electrochemical analysis of localized corrosion as well as pitting analysis from surface inspection such as pit density, pit depth and pit volume offer a more accurate indication of the pitting tendency of passive alloys in seawater.

Results from this study can be explained on the basis of the known potential-temperature dependence on the onset of localized corrosion in active-passive alloys. It is known that localized corrosion can take place if the corrosion potential of steel in a given environment surpasses a critical potential provided a critical temperature is exceeded $[13,56,57]$. The critical potential is usually considered to be the crevice corrosion repassivation potential $\left(E_{r}\right)$. At lower potentials than $E_{r}$, pit initiation is followed by rapid repassivation, a stage commonly referred to as metastable pitting. Both a critical potential and temperature are required to stabilize pit growth on the alloys surface. In a previous study, critical potentials and critical temperatures for pitting and crevice corrosion of high-resistance alloys in seawater were investigated [13]. It was observed that critical potentials for pitting and crevice corrosion initiation and repassivation decreased with increasing exposure temperature and lowering of temperature similarly ennobled the critical potential. In the same study, UNS S32750 and UNS S31254 exhibited excellent resistance to crevice corrosion in natural seawater at temperatures below $40^{\circ} \mathrm{C}$ under potentiostatic and potentiodynamic test conditions. This is in agreement with the results from the present study where UNS S32750, UNS S31254 and UNS N06625 remained protected against localized corrosion regardless of the presence and activity of a biofilm on their surfaces. On the other hand, UNS S31603, UNS S31803 and UNS N08825 seem to be prone to initiate localized corrosion at the seawater temperatures attained in our test rig as indicated by previous studies on their crevice corrosion repassivation potentials in seawater [13].

It is important to point out that results from previous investigations on the resistance of the alloys to localized corrosion in seawater were obtained using freshly ground coupons. In the presence of biofilms, a more aggressive microenvironment is created at the biofilm-metallic interphase which can facilitate localized corrosion initiation processes. Generally, these microfouling deposits present a patchy distribution on the metal surface so that the physical presence of a biofilm acts as a diffusion barrier that retards the movement of species from the bulk solution toward the metal surface and from the metal-biofilm interface outwards into the solution. Under these conditions, repassivation can be 
inhibited by limiting oxygen diffusion to the metallic surface leading to pit stabilization by differential aeration cell. In fact, biofilms have been reported to decrease initiation times for localized corrosion by lowering the critical initiation and repassivation potential for pitting and crevice corrosion $[14,16]$. It is very likely that the above mechanisms in conjunction with the observed ennoblement of the $E_{\text {corr }}$ compromised the stability of the passive film and assisted localized corrosion initiation provided the exposure temperature had exceeded a critical value. Moreover, ennoblement of $E_{\text {corr }}$ decreases the critical temperature below which a given alloy should be resistant to localized corrosion initiation.

Surface analysis also indicated that UNS S31603 suffered intergranular corrosion (IGC) only when exposed to raw untreated seawater. IGC is a form of localized corrosion along grain boundaries caused by anodic dissolution of specific regions at the surface such as regions depleted of alloying elements. Non-uniform intergranular attack can be due to factors that locally impair the corrosion process such as the formation of deposits. This may weaken the oxide film at specific locations, allowing halides such as chloride ions greater access to the underlying metal and facilitating localized attack. IGC has been previously reported for $70 \mathrm{Cu}-30 \mathrm{Ni}$ alloy under elliptical deposits of embedded diatoms [58] whereas IGC was not observed on the same alloy exposed to artificial seawater. It was suggested that dissolved sulphides produced by bacteria may have reacted with nickel in grain boundaries causing preferential dissolution of the steel in these regions. It has been shown that selective colonization by bacteria results in depletion of $\mathrm{Cr}$ and Fe relative to nickel at the grain boundaries on 316L stainless steel [59]. It was also reported that individual cells were seen along surface grain boundaries prior to biofilm formation suggesting that initial colonization is non-random and highly selective for grain areas. In addition, it was shown that sulphur compounds preferentially accumulate at grain boundaries particularly in the presence of sulphate-reducing bacteria (SRB). On the basis of these findings, it is reasonable to consider that microorganisms played a role in the onset of IGC of UNS S31603 exposed to raw seawater. However, since biofilms also formed on UNS S31603 exposed to UV treated seawater, where IGC was not detected, IGC cannot be attributed to the mere presence of microorganisms. Given that PCR-DGGE analysis revealed differences in the bacterial community in biofilms formed in raw and UV treated seawater, it is possible that IGC initiation could have been particularly favoured by the distinctive metabolic activities of the biofilm community developed in the raw seawater system. It is plausible to expect that microbial activity and biomass generation was higher in raw untreated seawater, where nutrients and organic matter are more abundant compared to the filtered-UV irradiated seawater.

PCR-DGGE method was used for directly determining the genetic diversity of microbial populations in the complex biofilms developed on the test alloys. PCR-DGGE analysis of biofilms formed on alloys exposed to filtered-UV treated seawater as well as raw untreated seawater indicated that filtration-UV irradiation had an effect on biofilm community composition. Changes in bacterial 
community in biofilms developed in treated seawater were likely associated with lower concentration of nutrients and organic matter due to filtration and settlement. PCR-DGGE also revealed that bacteria differed in their preference for material type. Different biofilm communities on different alloys have been reported previously [14]. It is likely that microbial adhesion and biofilm formation are affected by the nature of the passive film and the microstructure of alloys. Chemical composition and microstructure have been shown to have a strong influence on the composition and thickness of oxide films, which may contribute to the selective attachment of microorganisms.

Interestingly, a higher bacterial diversity was observed on alloys that exhibited some degree of pitting corrosion (UNS N08825, UNS S31603 and UNS S31803) compared to the alloys that displayed resistance to pitting. It is difficult, however, to discriminate between microbiological events that influenced pitting corrosion and corrosion reactions that influenced microbial settlement and diversity. The spatial distribution of bacteria on corroding surfaces has been previously investigated [60]. Autoradiography of ${ }^{14} \mathrm{C}$-acetate labelled bacteria on well-established anodic regions demonstrated that bacteria preferentially bound to sites of active anodic activity such as corrosion products formed over corrosion pits and inactive pits that has initiated and repassivated. It has been suggested that active corroding sites may offer alternative energy sources for bacterial growth on steel surfaces [61]. These studies, however, only measured bacterial density and did not evaluate bacterial diversity. Nonetheless, previous studies have found no correlation between bacterial diversity and localized corrosion in seawater $[16,37]$. From the present data it is difficult to infer any direct association between bacterial diversity in biofilms and localized corrosion events.

In addition, SEM revealed variations in physical structure and amount of EPS produced in biofilms according to substratum material. Differences in EPS production could be a bacterial mechanism to promote hydrophobic interactions to favour irreversible sorption onto solid surfaces [62]. The higher amount of EPS observed on nickel-based alloys compared to stainless steels, could suggest that there is a lower affinity between nickel oxide films and microbial cells compared to oxides formed on stainless steels. Likewise, the presence of toxic metals in the environment has been shown to stimulate EPS production by microorganisms [63] and the toxicity of nickel towards microorganisms is well documented [64]. Based on these reports, our findings could also suggest that EPS production was increased as a bacterial defence mechanism against toxic nickel species from corroding nickel-based alloys.

Results from this investigation highlight the impact of filtration, settlement and UV irradiation on corrosion performance and MIC in seawater. Although filtration-UV irradiation did not guarantee sterilization of the water and did not eradicate established biofilms it proved to be an efficient approach for mitigating biofilm growth and activity on corrosion resistant alloys in seawater. Filtration and settlement reduce the levels of nutrients and carbon sources in seawater which affects bacterial 
diversity in biofilms and limits biofilm growth and activity on alloys. In addition, filtration can reduce the number of biofouling organisms such as diatoms which are known to contribute to the corrosion of the steels. The use of filtration-UV irradiation to mitigate biofilm growth-associated effects on corrosion resistant alloys can provide an environmentally friendly practice to prevent MIC of subsea equipment. The appropriate use of this approach could contribute to reducing the overdosing of chemical biocides thus potentially decreasing the costs and impacts associated with their discharge to the environment. The technique however, is not effective against biofilms and hence should not be considered alone but rather in conjunction with other microbial control methods to fully protect subsea equipment against MIC.

\section{Conclusions}

Filtration-UV irradiation has promise as a microbial control method to prevent MIC of offshore construction alloys. Natural marine biofilms ennobled $E_{\text {corr }}$ of the stainless steels UNS S31603, UNS S31803, UNS S32750, UNS S31254 and the nickel alloys UNS N08825 and UNS N06625 by as much as $400-500 \mathrm{mV}$ relative to their initial $E_{\text {corr }}(\mathrm{Ag} / \mathrm{AgCl})$ within a few days of exposure to raw natural seawater. Treatment of seawater using filtration UV-C irradiation delayed microbial electrochemical activity on the alloy surfaces for up to 40 days which resulted in lower uniform and localized corrosion rates. Likewise, PCR-DGGE indicated that seawater treatment has an impact on biofilm community composition most likely due to the shortage of nutrients, organic matter and other colonizing organisms resulting from filtration and settlement.

Localized corrosion was only observed on carbon steel, UNS S31603 and, UNS N08825 and UNS S31803 and not detected on UNS S32750, UNS S31254 and UNS N06625 regardless of the presence of biofilms, most likely due to the high potential and temperature dependence of these alloys to initiate localized corrosion in natural seawater. Localized corrosion, as determined by pit depth and pit density analyses, was significantly higher in carbon steel, UNS N08825, UNS S31603 exposed to raw untreated seawater compared to exposures in treated seawater. UNS S31803 showed the lowest pitting corrosion between susceptible alloys with no significant differences between treated and untreated coupons.

Biofilm community composition differed on the various alloys which can be related to the nature of the passive films and the microstructure on the different alloys. In addition, SEM analysis showed differences in physical structure and EPS production in biofilms according to the type of material. On carbon steel, individual microbial cells were encrusted with corrosion products over the entire surface. Biofilms formed on nickel alloys appeared more abundant, complex and exhibited more copious amounts of EPS compared to the stainless steels. Despite the differences in biofilm morphology, structure and composition on the different alloys the extent of ennoblement was comparable between 
the alloys. Filtration-UV irradiation alone was not effective against biofilms in the long term and additional countermeasures would be necessary to fully protect a system against MIC.

\section{Acknowledgments}

The authors would like to thank Chevron Energy Technology Pty Ltd for the financial support and permission to publish this work. We also acknowledge the support of the Australian and Western Australian Governments and the North West Shelf Joint Venture Partners, as well as the Western Australian Energy Research Alliance (WA:ERA). The authors acknowledge the facilities, scientific and technical assistance of the Centre for Microscopy, Characterization \& Analysis at the University of Western Australia. We gratefully thank Dr. Kayley Usher from CSIRO Land and Water for her technical and scientific support with SEM imaging.

\section{References}

[1] P. Lens, A.P. Moran, T. Mahony, P. Stoody, V. O'Flaherty, biofilms in medicine industry and environmental biotechnology: Characteristics, analysis and control., IWA publishing London, UK., 2003.

[2] J.D. Bryers, Bacterial biofilms, Current Opinion in Biotechnology, 4 (1993) 197-204.

[3] T.R. Garrett, M. Bhakoo, Z. Zhang, Bacterial adhesion and biofilms on surfaces, Progress in Natural Science, 18 (2008) 1049-1056.

[4] V.S. Bhinu, Insight into Biofilm-Associated Microbial Life, Journal of Molecular Microbiology and Biotechnology, 10 (2005) 15-21.

[5] J.W. Patching, G.T.A. Fleming, Industrial biofilms: formation, problems and control., in: P. Lens, A.P. Moran, T. Mahony, P. Stoody, V. O'Flaherty (Eds.) Biofilms in medicine industry and environmental biotechnology: Characteristics, analysis and control., IWA publishing, London, UK., 2003

[6] P.S. Stewart, M.J. Franklin, Physiological heterogeneity in biofilms, Nature Reviews Microbiology, 6 (2008) 199-210.

[7] B.L. Purevdorj, P. Stoodley, The role of signaling in biofilm development, in: P. Lens, A.P. Moran, T. Mahony, P. Stoody, V. O'Flaherty (Eds.) biofilms in medicine industry and environmental biotechnology: Characteristics, analysis and control., IWA publishing London, UK., 2003, pp. 64-78.

[8] I.B. Beech, J. Sunner, Biocorrosion: towards understanding interactions between biofilms and metals, Current Opinion in Biotechnology 15 (2004) 181-186.

[9] F. Mansfeld, The interaction of bacteria and metal surfaces, Electrochimica Acta, 52 (2007) 76707680. 
[10] I.B. Beech, Corrosion of technical materials in the presence of biofilms--current understanding and state-of-the art methods of study, International Biodeterioration \& Biodegradation, 53 (2004) 177183.

[11] A. Iversen, B. Leffler, Aqueous Corrosion of Stainless Steels, in: R.T.J. A. (Ed.) Shreir's Corrosion, Elsevier, 2010, pp. 1802-1878.

[12] A.U. Malik, N.A. Siddiqi, S. Ahmad, I.N. Andijani, The effect of dominant alloy additions on the corrosion behavior of some conventional and high alloy stainless steels in seawater, Corrosion Science, 37 (1995) 1521-1535.

[13] L.L. Machuca, S.I. Bailey, R. Gubner, Systematic study of the corrosion properties of selected high-resistance alloys in natural seawater, Corrosion Science, 64 (2012) 8-16.

[14] L.L. Machuca, S.I. Bailey, R. Gubner, E. Watkin, A. Kaksonen, Microbiologically influenced corrosion of high-resistance alloys in seawater, in: NACE - International Corrosion Conference Series, Paper N. 11230, NACE International Houston, Texas, 2011.

[15] S.C. Dexter, Role of microfouling organisms in marine corrosion, Biofouling, 7 (1993) 97-127.

[16] L.L. Machuca, S.I. Bailey, R. Gubner, E. Watkin, A. Kaksonen, K. Heidersbach, Effect of oxygen and biofilms on crevice corrosion of UNS S31803 and UNS N08825 in natural seawater, Corrosion Science, 67 (2013) 242-255.

[17] M.J. Franklin, D.C. White, H.S. Isaacs, Pitting corrosion by bacteria on carbon steel, determined by the scanning vibrating electrode technique, Corrosion Science, 32 (1991) 945-952.

[18] P.J. Antony, S. Chongdar, P. Kumar, R. Raman, Corrosion of 2205 duplex stainless steel in chloride medium containing sulfate-reducing bacteria, Electrochimica Acta, 52 (2007) 3985-3994.

[19] M. Mehanna, R. Basseguy, M.L. Délia, A. Bergel, Effect of Geobacter sulfurreducens on the microbial corrosion of mild steel, ferritic and austenitic stainless steels, Corrosion Science 51 (2009) 2596-2604.

[20] S. Motoda, Y. Suzuki, T. Shinohars, S. Tsujikawa, The effect of marine fouling on the ennoblement of electrode potential for stainless steels, Corrosion Science, 31 (1990) 515-520.

[21] V. Scotto, M.E. Lai, The ennoblement of stainless steels in seawater: a likely explanation coming from the field, Corrosion Science, 40 (1998) 1007-1018.

[22] Jinsun Liao, Hitoshi Fukui, Tetsuya Urakami, H. Morisaki., Effect of biofilm on ennoblement and localized corrosion of stainless steel in fresh dam-water, Corrosion Science 52 (2010) 1393-1403.

[23] J. Landoulsia, C. Dagbert, C. Richard, R. Sabot, M. Jeannin, K.E. Kirat, S. Pulvin, Enzymeinduced ennoblement of AISI $316 \mathrm{~L}$ stainless steel: Focus on pitting corrosion behavior, Electrochimica Acta 54 (2009) 7401-7406.

[24] J. Landoulsi, M.J. Genet, C. Richard, K. El Kirat, P.G. Rouxhet, S. Pulvin, Ennoblement of stainless steel in the presence of glucose oxidase: Nature and role of interfacial processes, Journal of Colloid and Interface Science 320 (2008) 508-519. 
[25] A. Mollica, Biofilm and corrosion on active-passive alloys in seawater, International Biodeterioration \& Biodegradation 29 (1992) 213-229.

[26] S.C. Dexter, Mechanism of passivity breakdown in seawater: comprehensive final technical report in, Office of Naval Research, Arlington, VA., 2001.

[27] X. Congmin, Z. Yaoheng, C. Guangxu, Z. Wensheng, Localized corrosion behavior of 316L stainless steel in the presence of sulphate-reducing and iron-oxidizing bacteria, Materials Science and Engineering A 443 (2007) 235-241.

[28] L.L. Machuca, L. Murray, R. Gubner, S. Bailey, Evaluation of the effect of seawater ingress into 316L lined pipes on corrosion performance, Materials and Corrosion, doi: 10.1002/maco201206897, (2013).

[29] S.W. Borenstein, P.B. Lindsay, Microbiologically influenced corrosion failure analysis of 3041 stainless steel piping system left stagnant after hydrotesting with city water, in: Corrosion 2002, Paper N. 02446, NACE international, 2002.

[30] K. Zhao, T. Gu, I. Cruz, A. Kopliku, Laboratory investigation of MIC in hydrotesting using seawater, in: Corrosion 2010, Paper N. 10406, NACE International, 2010.

[31] A. Darwin, K. Annadorai, K. Heidersbach, Prevention of corrosion in carbon steel pipelines containing hydrotest water - an overview, in: Corrosion 2010, Paper 10401, NACE International, 2010.

[32] J.E. Penkala, J. Fichter, S. Ramachandran, Protection against microbiologically influenced corrosion by effective treatment and monitoring during hydrotest shut-in, in: Corrosion 2010, Paper N.10404, NACE International, 2010.

[33] V. Raman, S. Tamilselvi, N. Rajendran, Evaluation of effective biocides for SRB to control microbiologically influenced corrosion, Materials and Corrosion 59 (2008) 329-334.

[34] R. Prasad, Chemical Treatment Options for Hydrotest Water to Control Corrosion and Bacterial Growth, in: Corrosion 03, Paper N. 03572, NACE International, San Diego Ca, 2003.

[35] M.O. Elasri, R.V. Miller, Study of the response of a biofilm bacterial community to UV radiation, Applied and Environmental Microbiology, 65 (1999) 2025-2031.

[36] R.J. Jeffrey, R.E. Melchers, The effect of microbiological involvement on the topography of corroding mild steel in coastal seawater, in: Corrosion 10, Paper N. 10224, NACE International 2010. [37] L.L. Machuca, S.I. Bailey, R. Gubner, E. Watkin, M.P. Ginige, A. Kaksonen, Bacterial community structure in natural marine biofilms and the corrosion of carbon steel in seawater, in: 18th International Corrosion Congress, Paper 371, Perth, Australia, 2011.

[38] X.Y. Zhu, J. Lubeck, J.J. Kilbane II, Characterization of Microbial Communities in Gas Industry Pipelines, Applied and Environmental Microbiology 69 (2003) 5354-5363.

[39] I. Neria-Gonzalez, E.T. Wang, F. Ramirez, J.M. Romero, C. Hernandez-Rodriguez, Characterization of bacterial community associated to biofilms of corroded oil pipelines from the southeast of Mexico, Anaerobe 1212 (2006) 122-133. 
[40] F. Teng, Y.T. Guan, W.P. Zhu, Effect of biofilm on cast iron pipe corrosion in drinking water distribution system: Corrosion scales characterization and microbial community structure investigation, Corrosion Science, 50 (2008) 2816-2823.

[41] G. Muyzer, T. Brinkhoff, U. Nubel, C. Santegoeds, H. Shafer, C. Wawer, Denaturing Gradient Gel Electrophoresis (DGGE) in microbial ecology, in: George A. Kowalchuk, Frans J. de Bruijin, I.M. Head, Antoon D.L. Akkermans, J.D.c. Elsas (Eds.) Molecular Microbial Ecology Manual, Kluwer Academic Publishers, 2004.

[42] J.S. Patil, H. Kimoto, T. Kimoto, T. Saino, Ultraviolet radiation (UV-C): a potential tool for the control of biofouling on marine optical instruments, Biofouling, 23 (2007) 215 - 230.

[43] ASTM, G 1-03: Standard Practice for Preparing, Cleaning, and Evaluating Corrosion Test Specimens, in, ASTM International, 2003, pp. 1-9.

[44] D.J. Lane, 16S/23S rRNA sequencing, in: E.S.a.M. Goodfellow (Ed.) Nucleic acid techniques in bacterial systematics, John Wiley and Sons, Chichester, England., 1991, pp. 115-175.

[45] G. Muyzer, S. Hottentrager, A. Teske, C. Wawer, Denaturing gradient gel electrophoresis of PCR-amplified 16S rDNA-a new molecular approach to analyse the genetic diversity of mixed microbial communities, in: A.D.L. Akkermans, J.D.V. Elsas, F.D. Bruijn (Eds.) Molecular microbial ecology manual, Kluwer Academic Publishers, Dordrecht, The Netherlands, 1996, pp. 3.4.4/13.4.4/23.

[46] B.J. Little, J.L. Lee, R.I. Ray, The influence of marine biofilms on corrosion: A concise review, Electrochimica Acta, 54 (2008) 2-7.

[47] W.H. Dickinson, F. Caccayo Jr, Z. Lewandowski, The ennoblement of stainless steel by manganic oxide biofouling, Corrosion Science, 38 (1996) 1407-1422.

[48] M.O. Elasry, R.V. Miller, Study of the Response of a Biofilm Bacterial Community to UV Radiation, Applied and Environmental Microbiology, 65 (1999) 2025-2031.

[49] H.A. Videla, Biofilms and corrosion interactions on stainless steels in seawater, International Biodeterioration \& Biodegradation, 34 (1994) 245-257.

[50] K. Mattila, L. Carpen, T. Hakkarainen, M.S. Salkinoja-Salonen, Biofilm Development During Ennoblement of Stainless Steel in Baltic Sea Water: A Microscopic Study, International Biodeterioration \& Biodegradation, 40 (1997) 1-10.

[51] V. Scotto, R. Di Cintio, G. Marcenaro, The influence of marine aerobic microbial film on the stainless steel corrosion behaviour Corrosion Science, 25 (1985) 185-194.

[52] S.C. Dexter, Mechanism of passivity breakdown in seawater, in, Office of Naval Research, Arlington, VA, 2001, pp. 1-167.

[53] M. Eashwar, S. Maruthamuthu, S. Sathiyanarayanan, K. Balakrishnan, The ennoblement of stainless alloys by marine biofilms: the neutral ph and passivity enhancement model, Corrosion Science, 37 (1995) 1169-1176. 
[54] H. Venzlaff, D. Enning, J. Srinivasan, K.J.J. Mayrhofer, A.W. Hassel, F. Widdel, M. Stratmann, Accelerated cathodic reaction in microbial corrosion of iron due to direct electron uptake by sulfatereducing bacteria, Corrosion Science, 66 (2013) 88-96.

[55] B.W.A. Sherar, I.M. Power, P.G. Keech, S. Mitlin, G. Southam, D.W. Shoesmith, Characterizing the effect of carbon steel exposure in sulfide containing solutions to microbially induced corrosion, Corrosion Science 53 (2011) 955-960.

[56] R. Qvarfort, Critical pitting temperature measurements of stainless steels with an improved electrochemical method, Corrosion Science, 29 (1989) 987-993.

[57] P.T. Jakobsen, E. Maahn, Temperature and potential dependence of crevice corrosion of AISI 316 stainless steel, Corrosion Science, 43 (2001) 1693-1709.

[58] F. Mansfeld, G. Liu, H. Xiao, C.H. Tsai, B.J. Little, The corrosion behavior of copper alloys, stainless steels and titanium in seawater Corrosion Science, 36 (1994) 2063-2095.

[59] G.G. Geesey, R.J. Gillis, R. Avci, D. Daly, M. Hamilton, P. Shope, G. Harkin, The influence of surface features on bacterial colonization and subsequent substratum chemcial changes of $316 \mathrm{~L}$ stainless steel, Corrosion Science, 38 (1996) 73-95.

[60] F. Franklin, D.C. White, B.J. Little, R. Ray, R. Pope, The role of bacteria in pit propagation of carbon steel, Biofouling, 15 (2000).

[61] B.V. Kjellerup, B.H. Olesen, J.L. Nielsen, K.R. SowerS, P.H. Nielsen, In situ detection of bacteria involved in cathodic depolarization and stainless steel surface corrosion using microautoradiography, Journal of Applied Microbiology, 105 (2008) 2231-2238.

[62] J. Azeredo, R. Oliveira, The role of hydrophobicity and exopolymers in initial adhesion and biofilm formation in: P. Lens, A.P. Moran, T. Mahony, P. Stoody, V. O'Flaherty (Eds.) biofilms in medicine industry and environmental biotechnology: Characteristics, analysis and control., IWA publishing London, UK., 2003.

[63] Herbert H.P. Fang, Li-Chong Xu, K.-Y. Chan, Effects of toxic metals and chemicals on biofilm and biocorrosion, Water Research, 36 (2002) 4709-4716.

[64] L. Macombera;, R.P. Hausinger., Mechanisms of nickel toxicity in microorganisms, Metallomics, 3 (2011) 1153-1162. 


\section{Figures}

Figure 1. $E_{c o r r}$ as a function of time for test materials exposed to raw seawater and filtered-UV irradiated (treated) seawater. [a] UNS S31603; [b] UNS S31803; [c] UNS S32750; [d] UNS S31254; [e] UNS N06625; [f] UNS N08825 and [g] carbon steel.

Figure 2. Variation of temperature over time for flowing raw and treated seawater in the experiments.

Figure 3. Corrosion rates by weight loss of test materials exposed to flowing natural costal seawater for 90 days. [a] high-resistance alloys in raw and treated seawater (corrosion rates given in $\mu \mathrm{m} \mathrm{y}^{-1}$ ) and

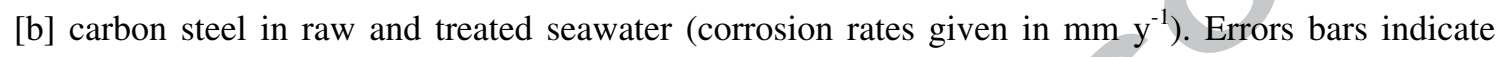
standard deviations from triplicate samples.

Figure 4. 3D optical microscope surface images of carbon steel exposed to flowing natural coastal seawater under open-circuit conditions after biofilm removal and surface cleaning. [a] Localized corrosion on coupons exposed to raw seawater. Localized attack was more severe on the coupon edges with maximum depth of attack of $500 \mu \mathrm{m}$; [b] Severe pitting on coupon exposed to treated seawater; maximum depth of attack of $50 \mu \mathrm{m}$. Coupon edges were not affected.

Figure 5. Surface analysis of UNS S31603, UNS S31803 and UNS N08825 exposed to flowing raw and treated seawater. [a] average pit density $\left(\right.$ pits $\mathrm{cm}^{-2}$ ); errors bars indicate standard deviations from duplicate samples and $[\mathrm{b}]$ average pit depth $(\mu \mathrm{m})$; errors bars show the range of pit depths found for each alloy.

Figure 6. 3D optical surface image showing intergranular corrosion (IGC) on UNS S31603 exposed to raw seawater. IGC was not observed on UNS S31603 exposed to treated seawater.

Figure 7. SEM micrographs of biofilms formed on the various test materials exposed to flowing coastal seawater. [a] biofilm containing microbial cells and diatoms (indicated by arrows) embedded in extracellular polymeric substance (EPS) on UNS S31803 exposed to raw seawater; [b] biofilms consisting of mats of fused overlapping material and net-like structures formed on UNS S31603 exposed to treated seawater; [c] mature biofilm showing microbial cells embedded in abundant EPS on UNS S32750 exposed to treated seawater; [d] dense and complex biofilm formed showing diatoms and microbial cells, filamentous structures and diatoms embedded in copious amounts of EPS with connecting structures formed on UNS N08825 exposed to raw seawater; [e] microbial cells encrusted with corrosion products over the surface of carbon steel coupons exposed to raw seawater. A close-up 
of the same surface highlights an individual microbial cell (pointed out by a white arrow) on corrosion products.

Figure 8. PCR-DGGE profiles of dominant bacterial populations in biofilms formed on the different test materials exposed to both raw and treated seawater. Each lane of the gel corresponds to one biofilm community and each band theoretically corresponds to one bacterial population in each biofilm community. Red circles highlight at least one of the distinctive bands (populations) that were unique to the raw or the UV treated seawater biofilm for each test material.

\section{Highlights}

> Biofilms ennobled $E_{\text {corr }}$ of offshore construction alloys in natural seawater.

> Filtration-UV irradiation delayed biofilm growth and activity on alloys.

$>$ Localized corrosion in seawater was lowered by the use of filtration-UV irradiation.

Biofilm community composition was affected by both substratum and seawater treatment.

> Filtration-UV irradiation can be an ecofriendly practice for protection against MIC. 
Table 1. Test materials and their chemical composition.

\begin{tabular}{|c|c|c|c|c|c|c|c|c|c|c|}
\hline Material & Type & $\mathrm{C}$ & $\mathrm{Mn}$ & $\mathrm{Fe}$ & $\mathrm{Cr}$ & $\mathrm{Ni}$ & Mo & $\mathrm{N}$ & $\mathrm{Nb}$ & $\mathrm{S}$ \\
\hline & & wt $\%$ & wt $\%$ & $\begin{array}{l}\mathrm{wt} \\
\%\end{array}$ & wt $\%$ & wt $\%$ & wt $\%$ & wt $\%$ & $\begin{array}{l}\mathrm{wt} \\
\%\end{array}$ & wt $\%$ \\
\hline UNS S31603 & Austenitic SS & 0.022 & 1.76 & bal & 17.4 & 10 & 2.03 & 0.046 & - & 0.001 \\
\hline UNS S31803 & Duplex SS & 0.015 & 1.53 & bal & 22.35 & 5.72 & 3.16 & 0.18 & - & 0.001 \\
\hline UNS S32750 & Super Duplex SS & 0.019 & 0.819 & bal & 24.74 & 6.61 & 3.73 & 0.262 & $-\infty$ & 0.0003 \\
\hline UNS S31254 & Super austenitic SS & 0.01 & - & bal & 20.18 & 18.15 & 6.1 & 0.2 & - & 0.010 \\
\hline UNS N08825 & Nickel base alloy & 0.05 & 0.85 & 22 & 22.5 & bal & 3 & - & - & 0.03 \\
\hline UNS N06625 & Nickel base alloy & 0.1 & 0.45 & 5 & 22.5 & bal & 9 & - & 3.85 & 0.015 \\
\hline Carbon steel & ASTM A572-50 & $\begin{array}{l}\text { C } 0.155, \mathrm{Al} \\
0.025, \mathrm{Mn} \\
0.65, \mathrm{P} \\
0.020, \mathrm{~S} \\
0.010, \mathrm{Si} \\
0.15 .\end{array}$ & & & & & & & & \\
\hline
\end{tabular}

Table 2. Characteristics of the coastal seawater at the experimental rig (Taylors Beach, NSW, Australia) during the period of this study.

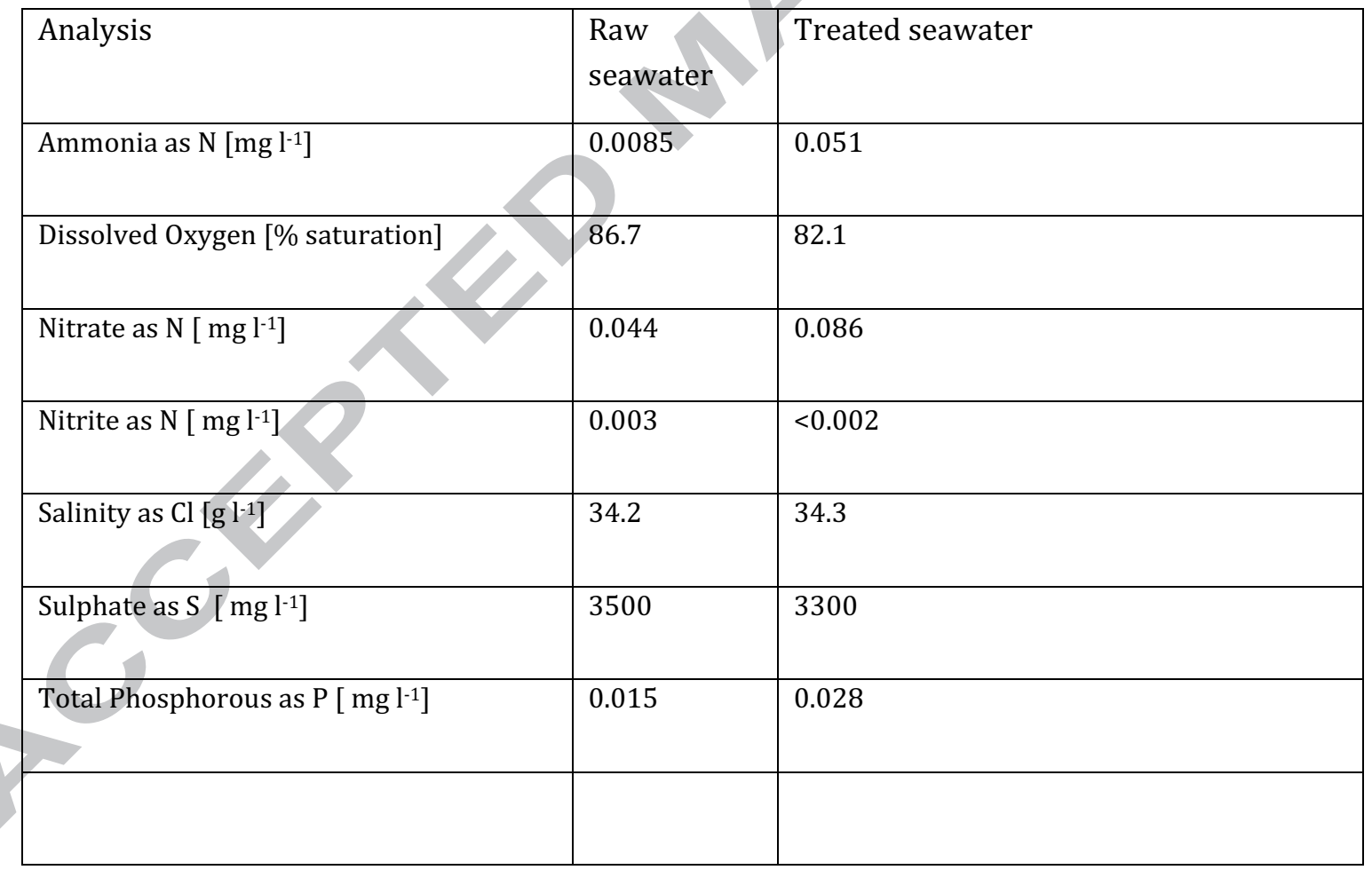


Table 3. Primers used in this study for the amplification of the full-length and variable region of the bacterial 16S rRNA gene.

\begin{tabular}{|c|c|c|c|c|}
\hline & $\begin{array}{l}\text { Prim } \\
\text { er }^{\mathrm{a}}\end{array}$ & & $\begin{array}{l}\text { Amplificat } \\
\text { ion target }\end{array}$ & $\begin{array}{l}\text { Sequen } \\
\text { ce }(5\end{array}$ \\
\hline $27 F^{b}$ & & Bacteria & & GAGTTTGATCCTGGCTCAG \\
\hline $357 \mathrm{~F}$ & & Bacteria & & CCTACGGGAGGCAGCAG \\
\hline $357 \mathrm{~F}-\mathrm{GC}^{\mathrm{c}}$ & & Bacteria & & CCTACGGGAGGCAGCAG \\
\hline $1492 R^{b, d}$ & & Prokaryotes & & $\begin{array}{l}\text { ACGGdITACCTTGTTACGAC } \\
\text { TT }\end{array}$ \\
\hline $907 \mathrm{R}^{\mathrm{b}}$ & & Universal & & $\begin{array}{l}\text { CCG TCA ATT CMT TTG } \\
\text { AGT T }\end{array}$ \\
\hline
\end{tabular}

${ }^{a}$ The number relates to the Escherichia coli position to which the 3' end of the primers anneals. F and R correspond to forward and reverse primers, respectively.

${ }^{\mathrm{b}}$ Modified from the original paper

' $\mathrm{GC}$ is a 40 nucleotide GC-rich sequences attached to the 5' end of the primer. The GC sequence is 5 -

CGCCCGCCGCGCGCGGCGGGCGGGGCGGGGGCACGGGGGG.

${ }^{d} \mathrm{dI}$ denotes a deoxyinosine modification. 


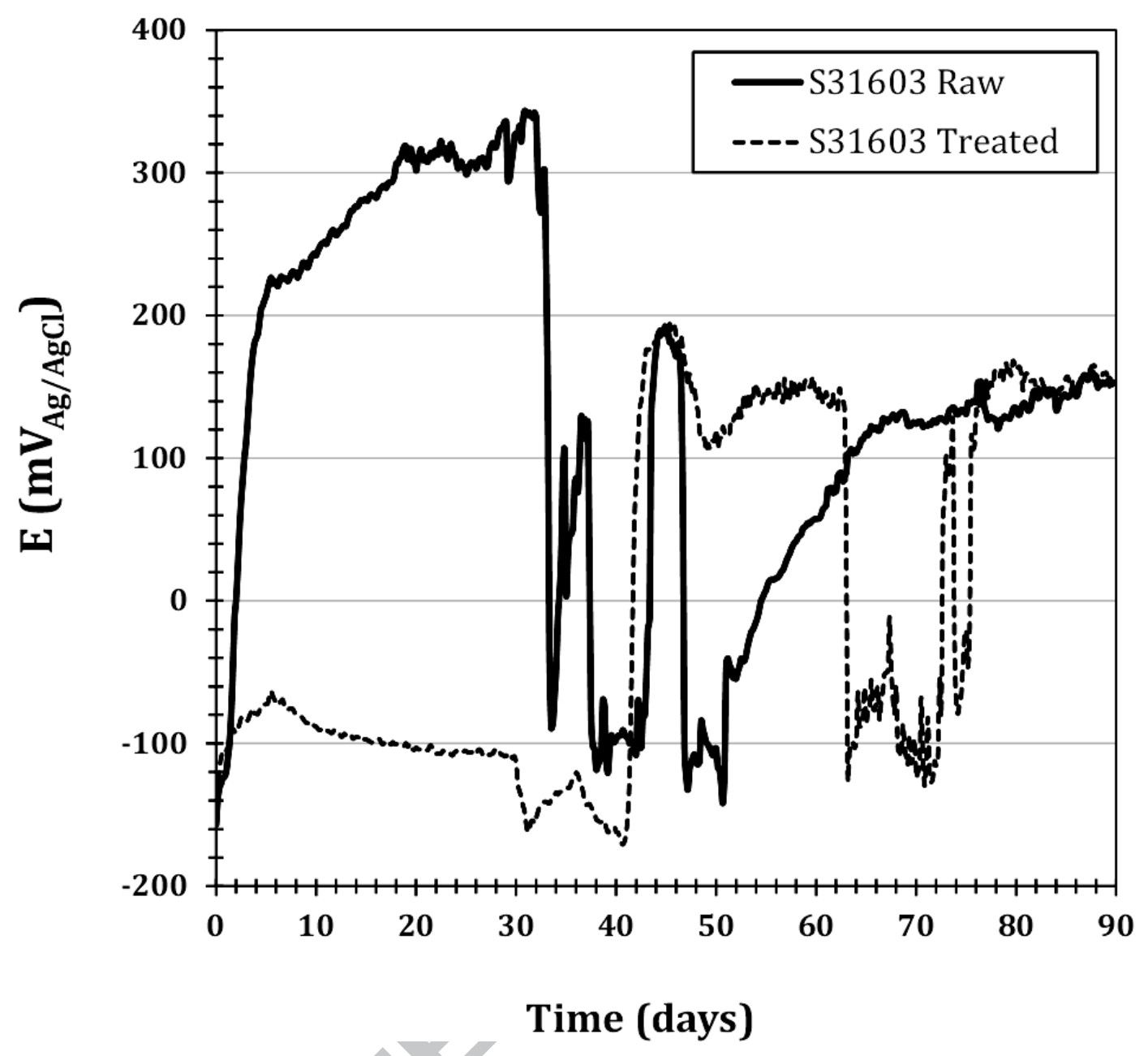


Figure 1.b

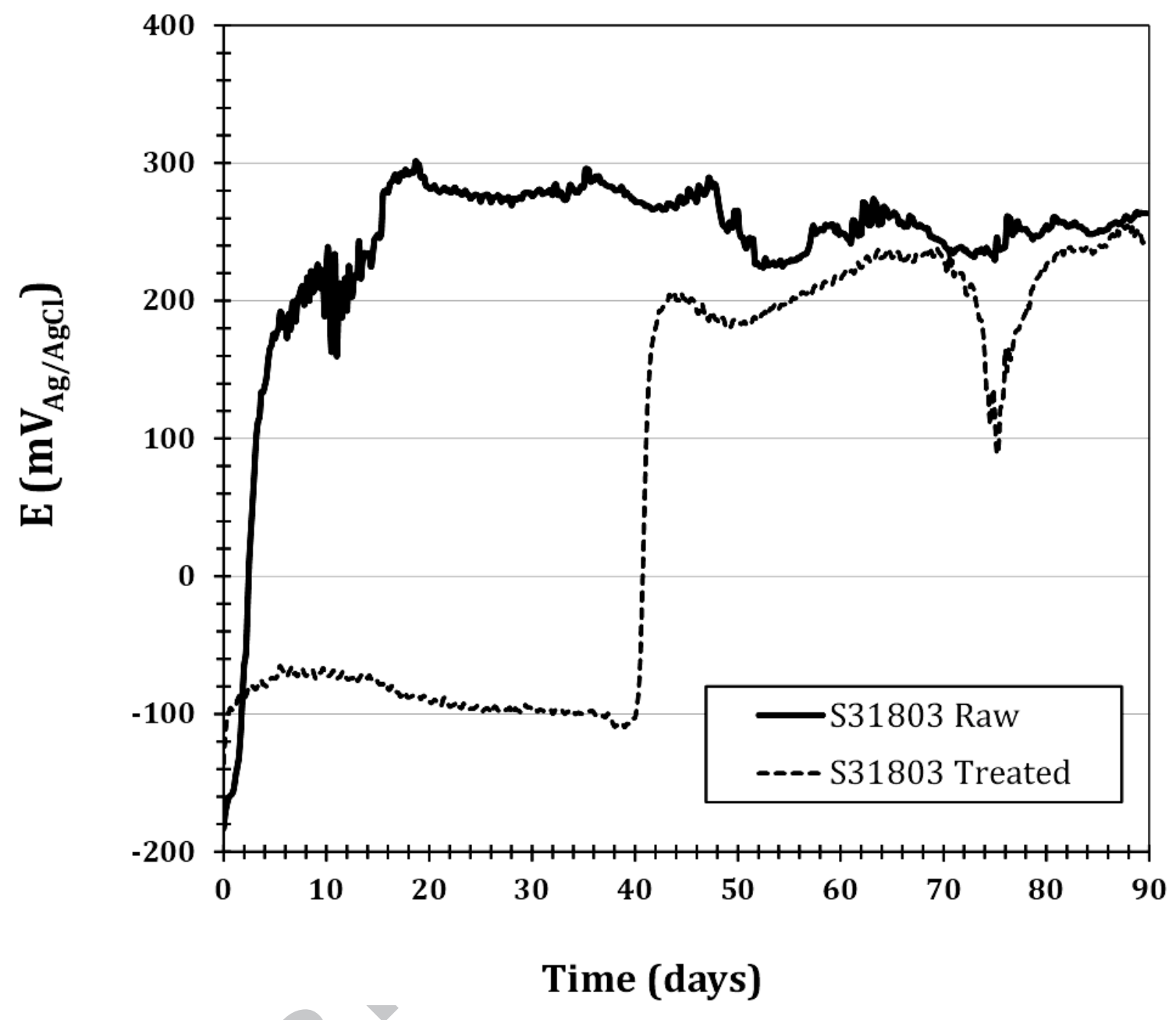


Figure 1.c

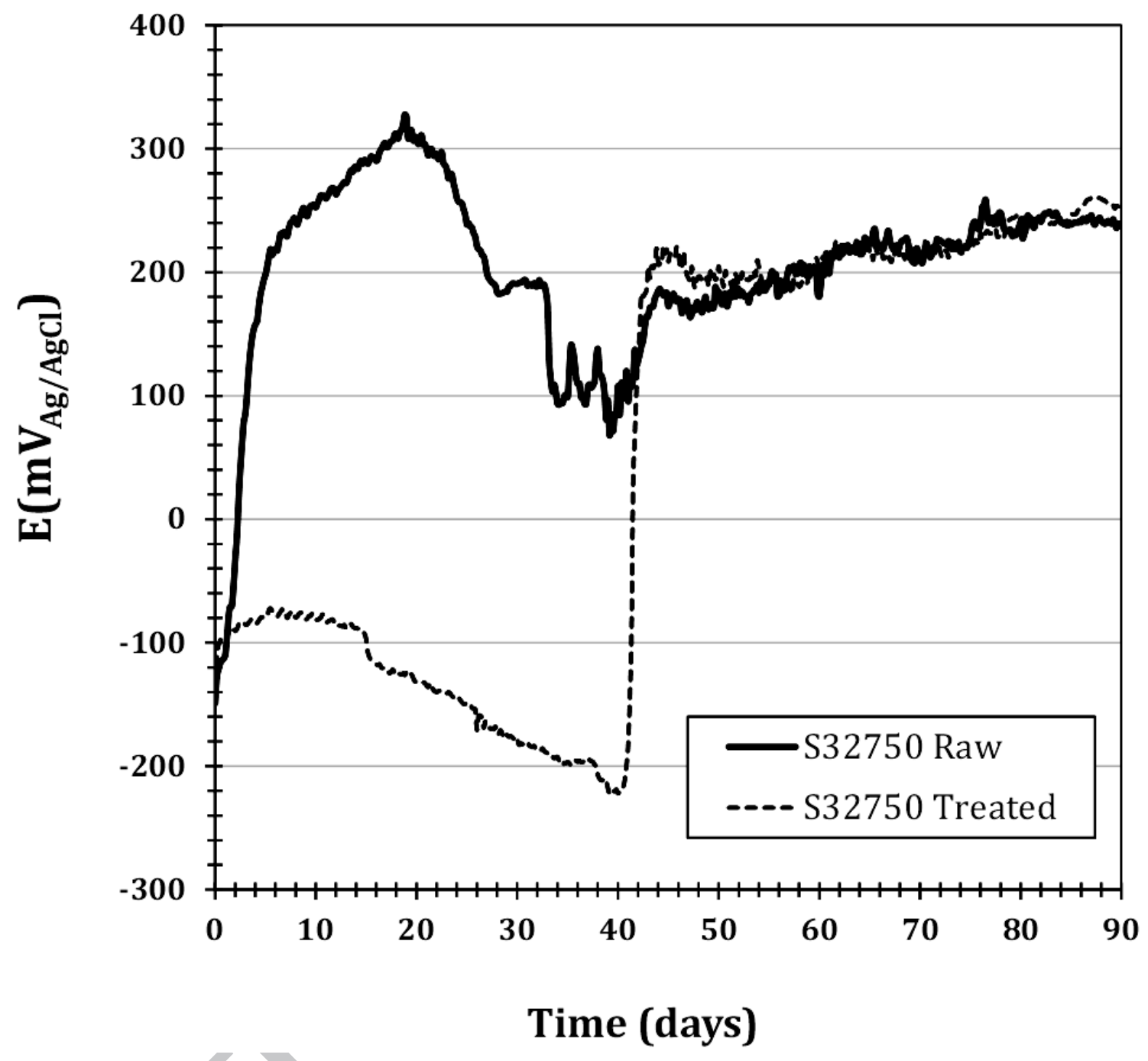


Figure 1.d

\section{ACCEPTED MANUSCRIPT}

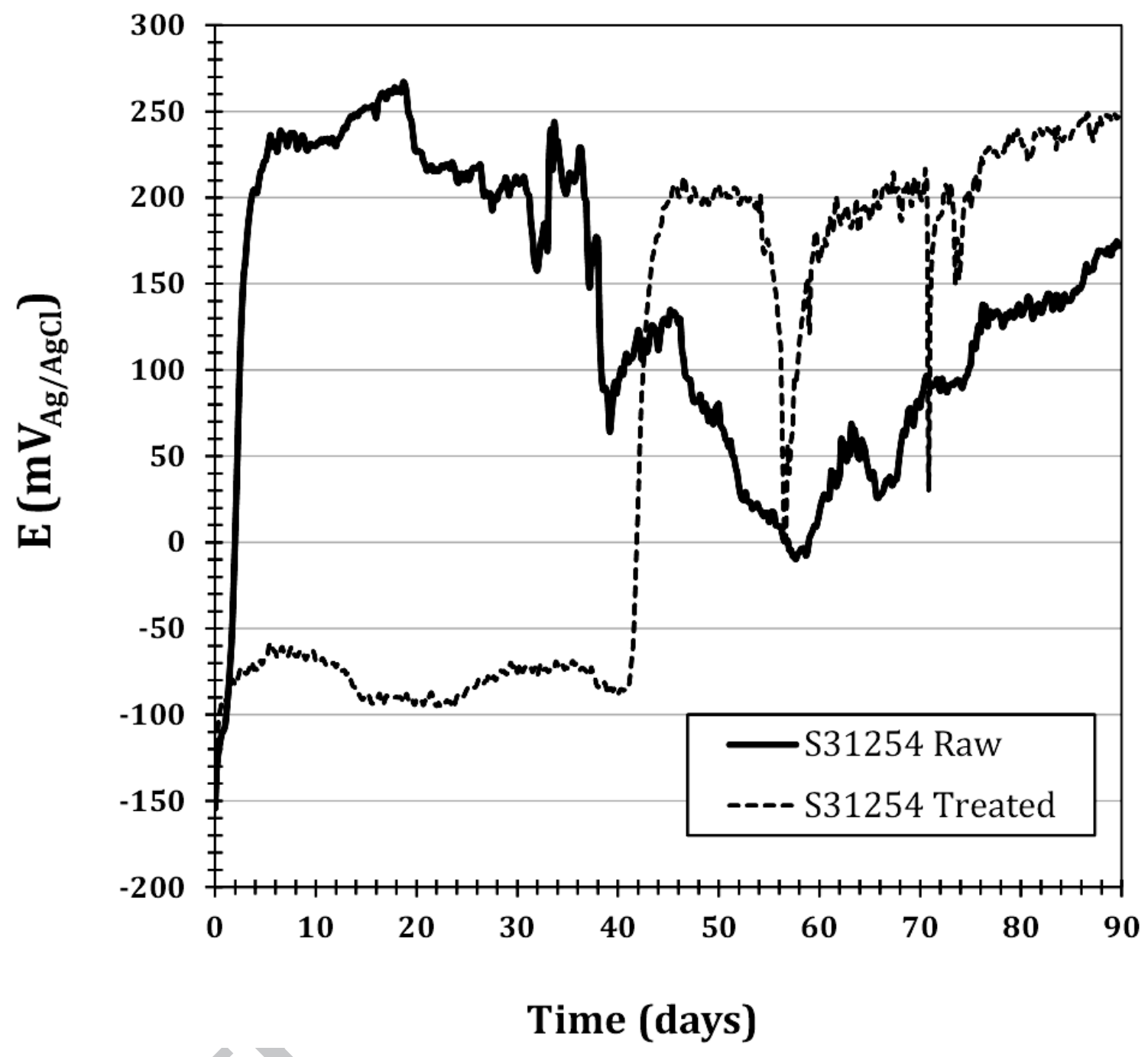




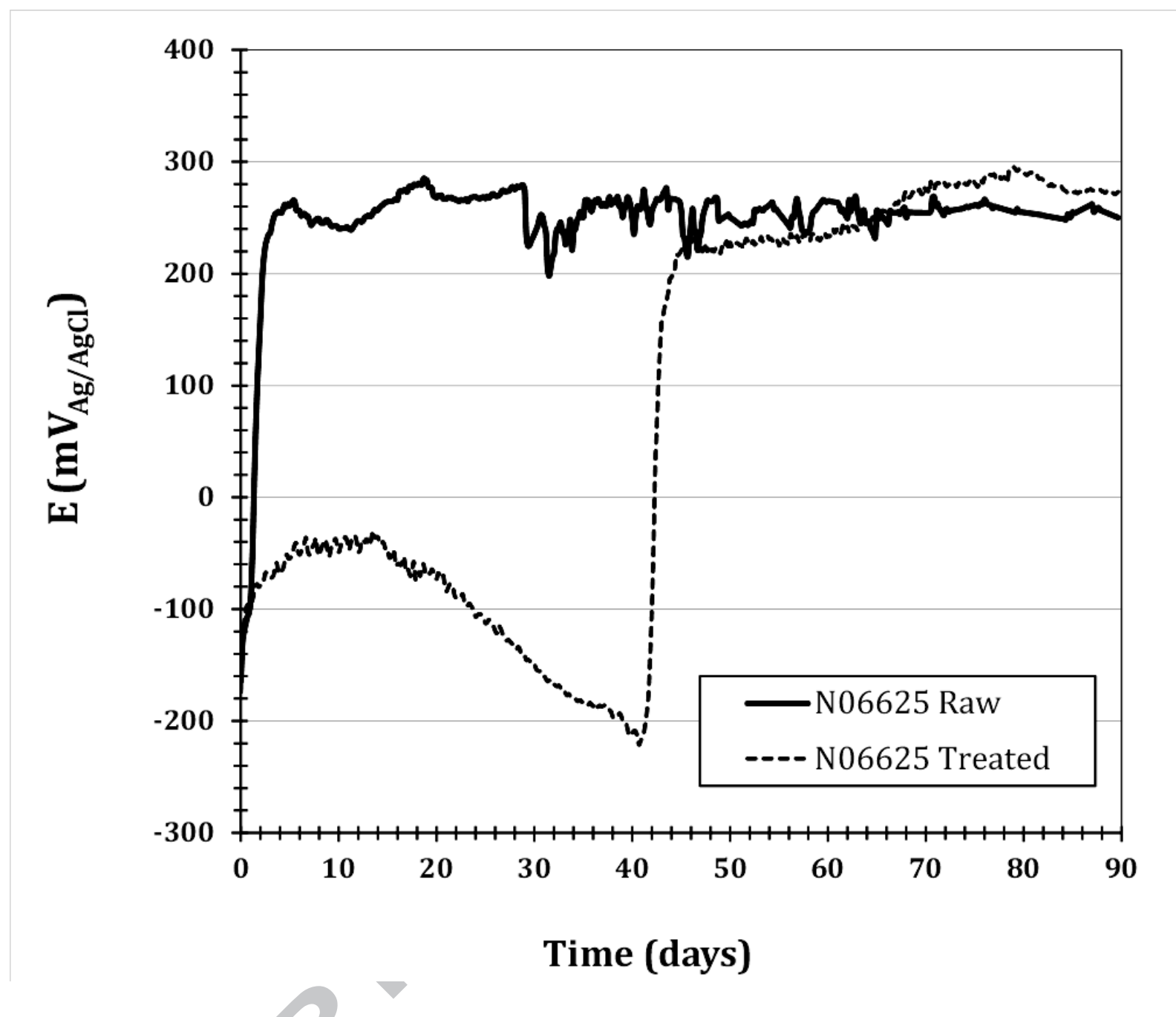

Figure 1.e

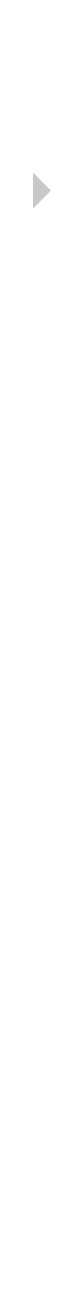

\section{ACCEPTED MANUSCRIPT}




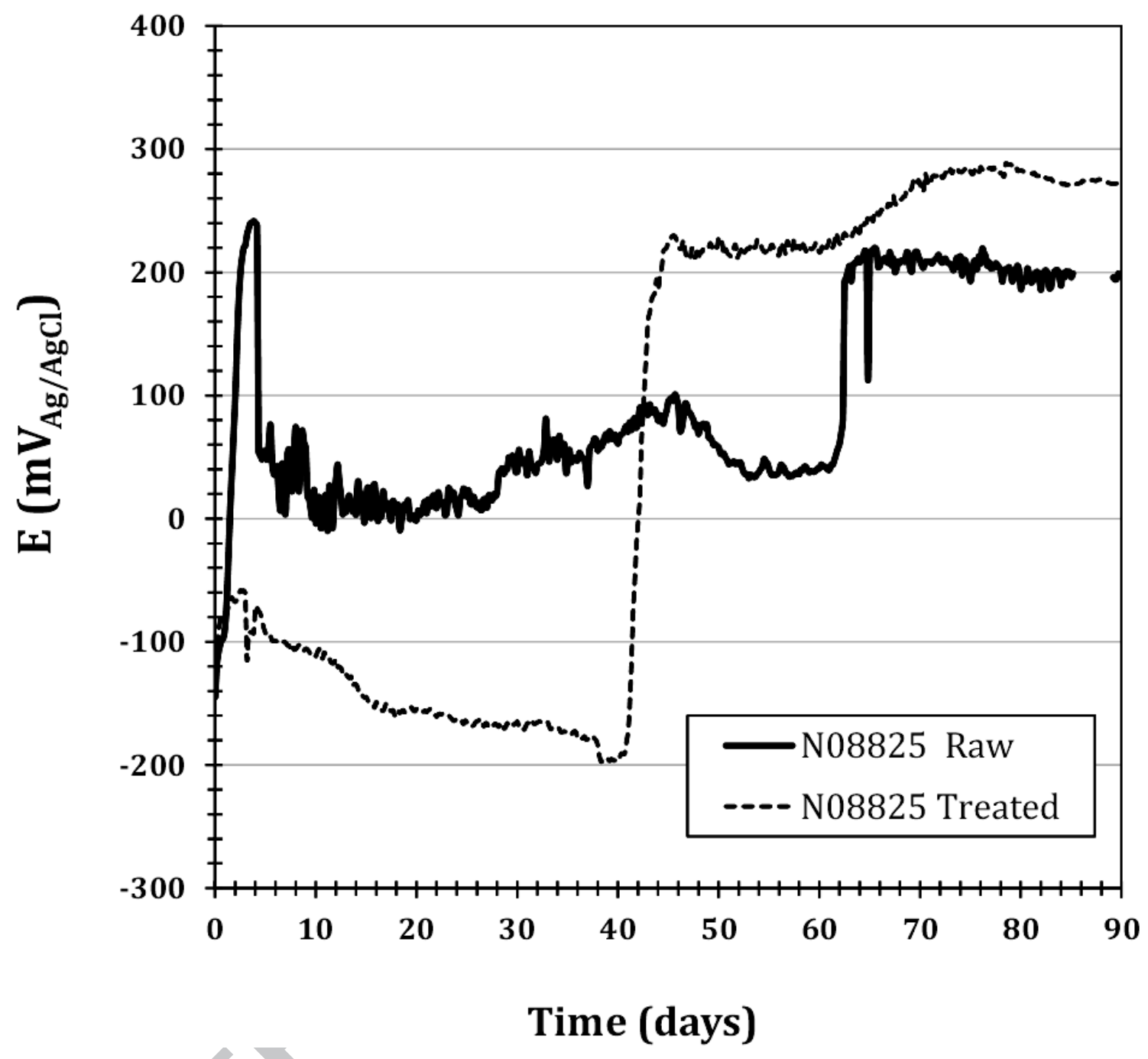




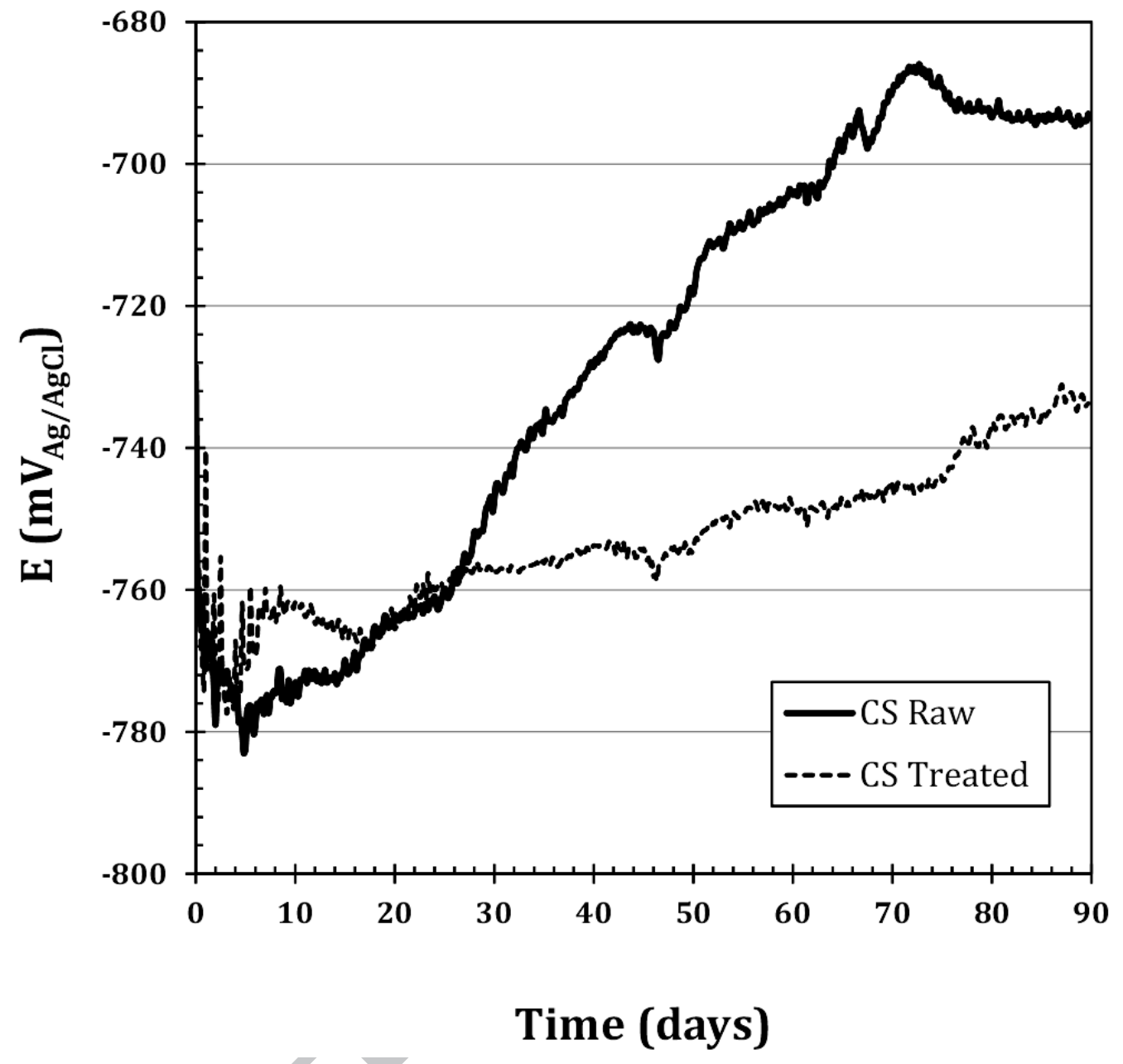




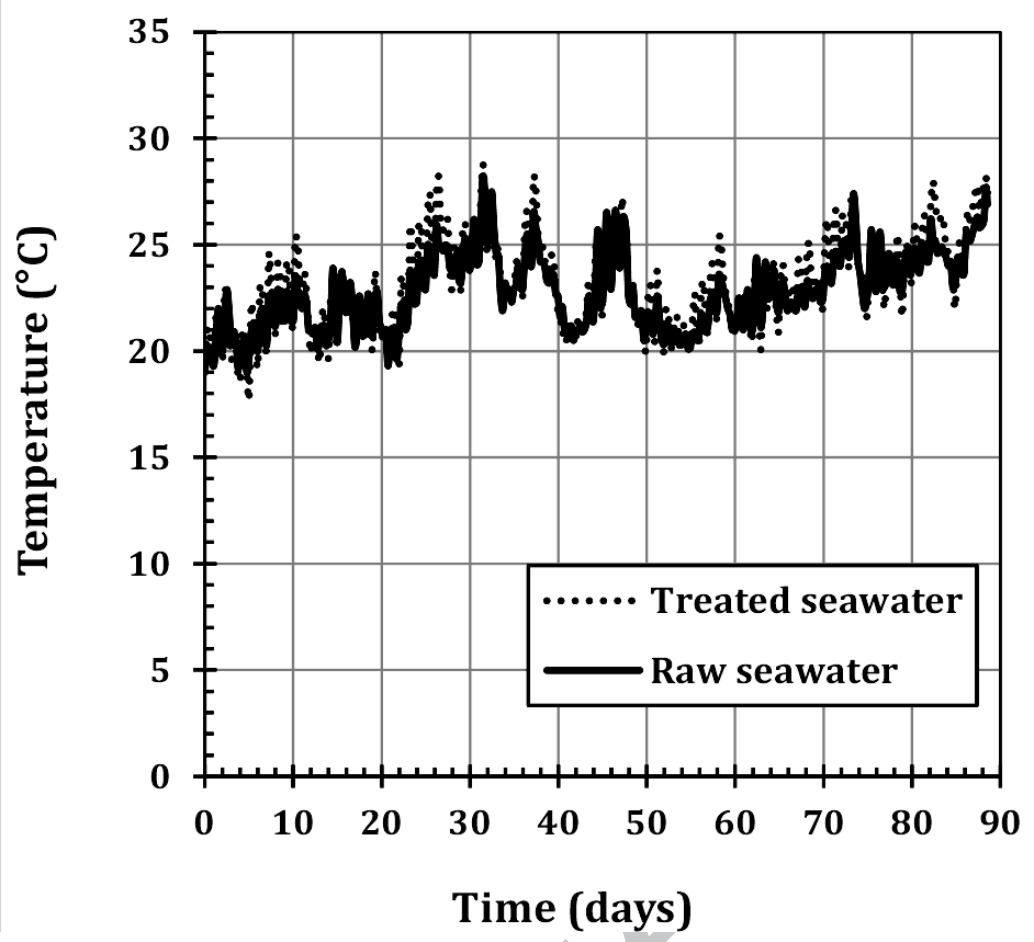




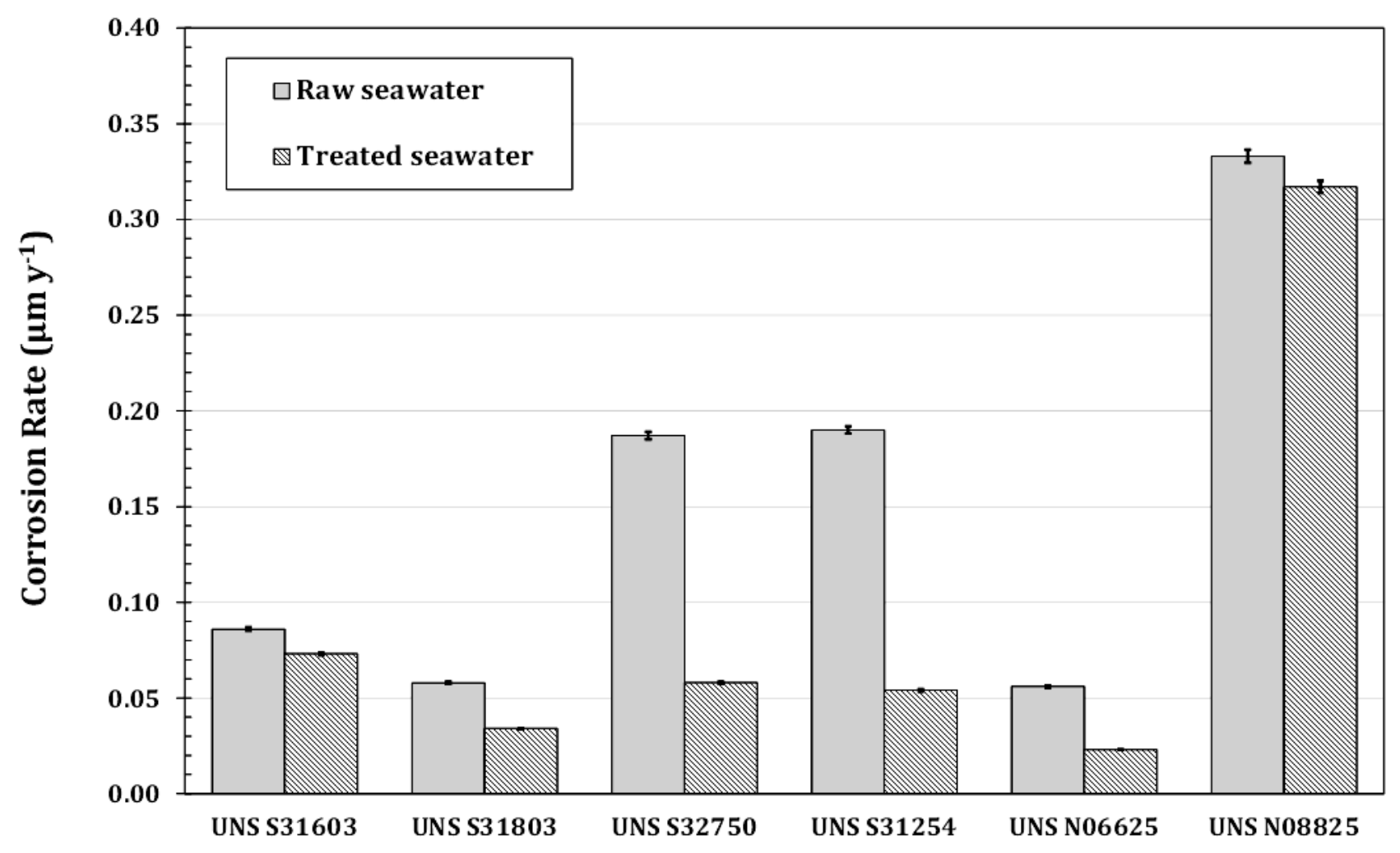




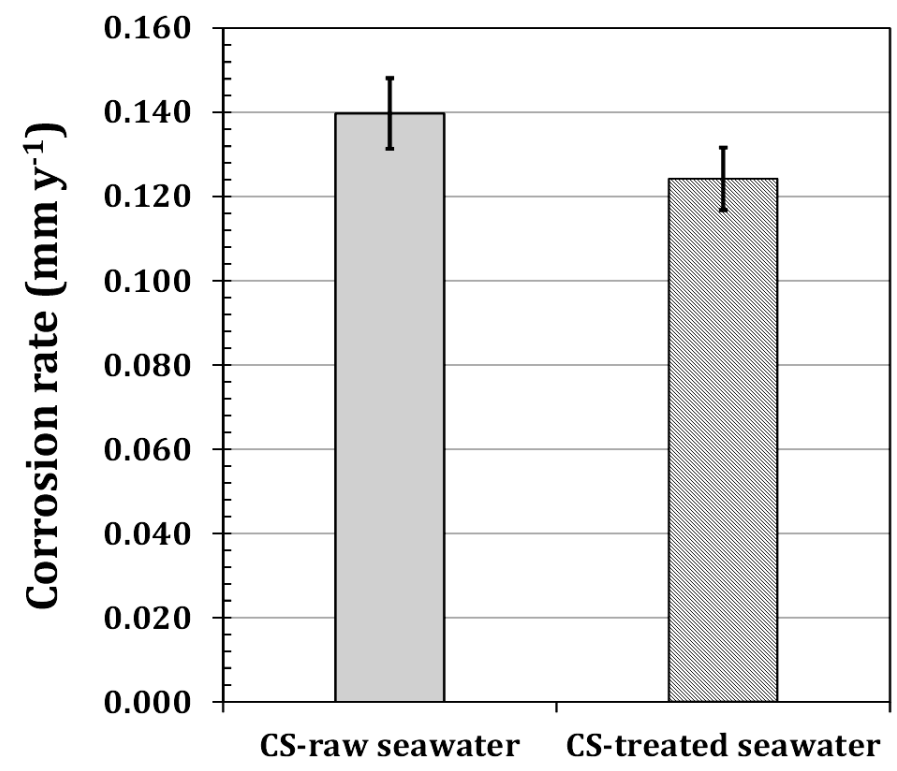


ACCEPTED MANUSCRIPT

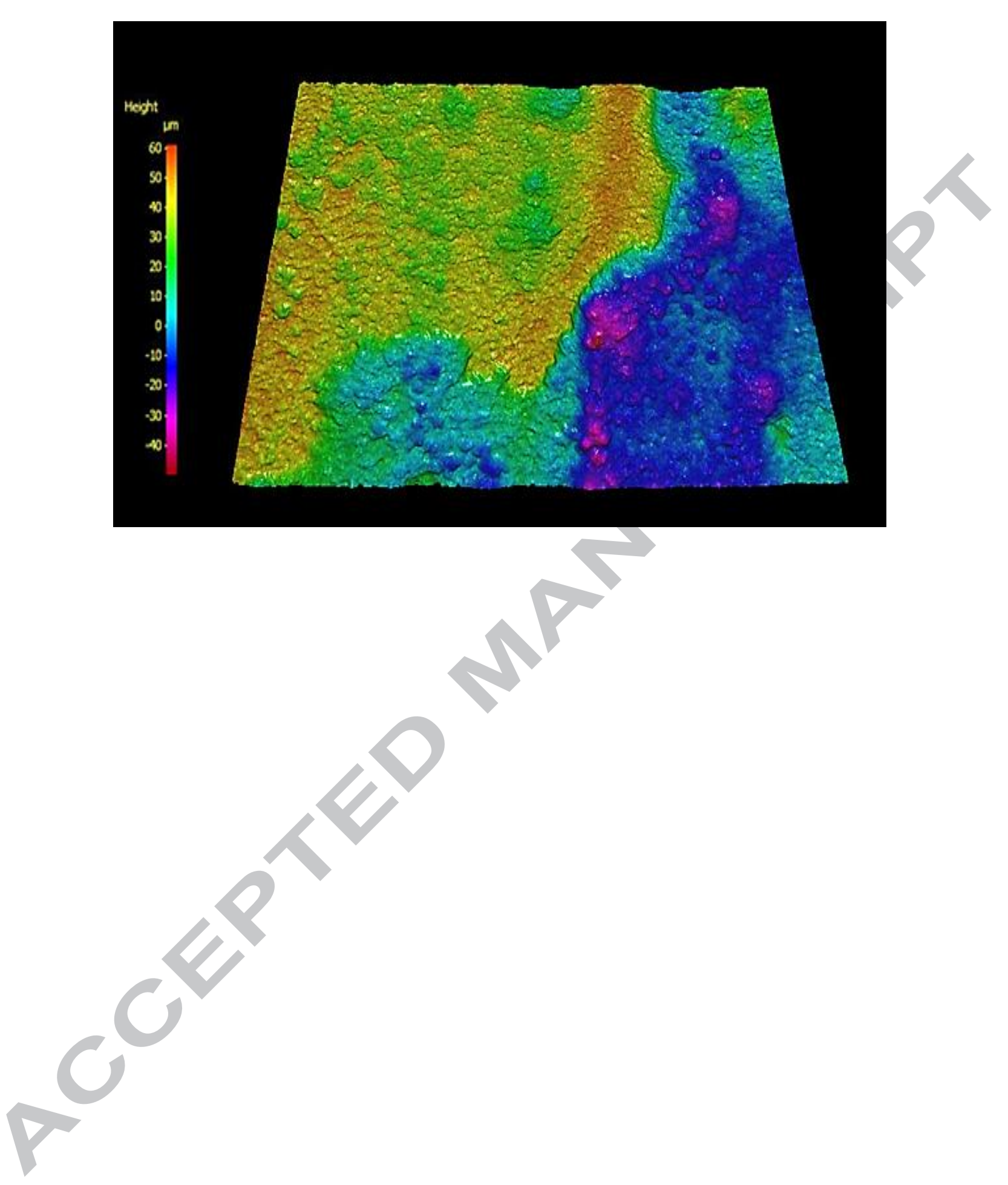

Figure 4.a (color)

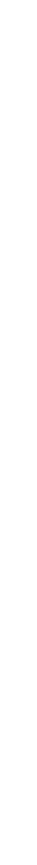


ACCEPTED MANUSCRIPT

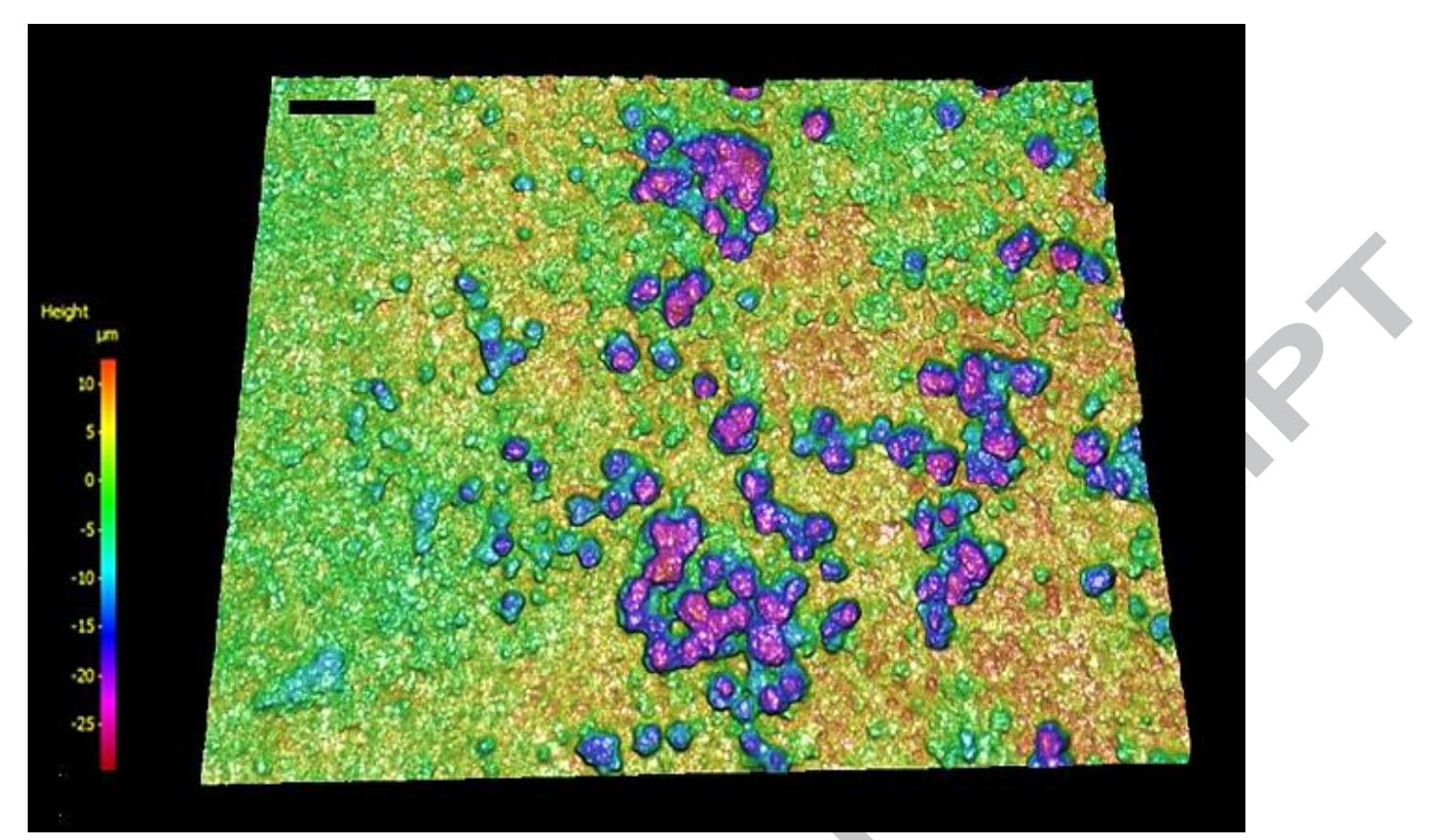

Figure 4.b (color
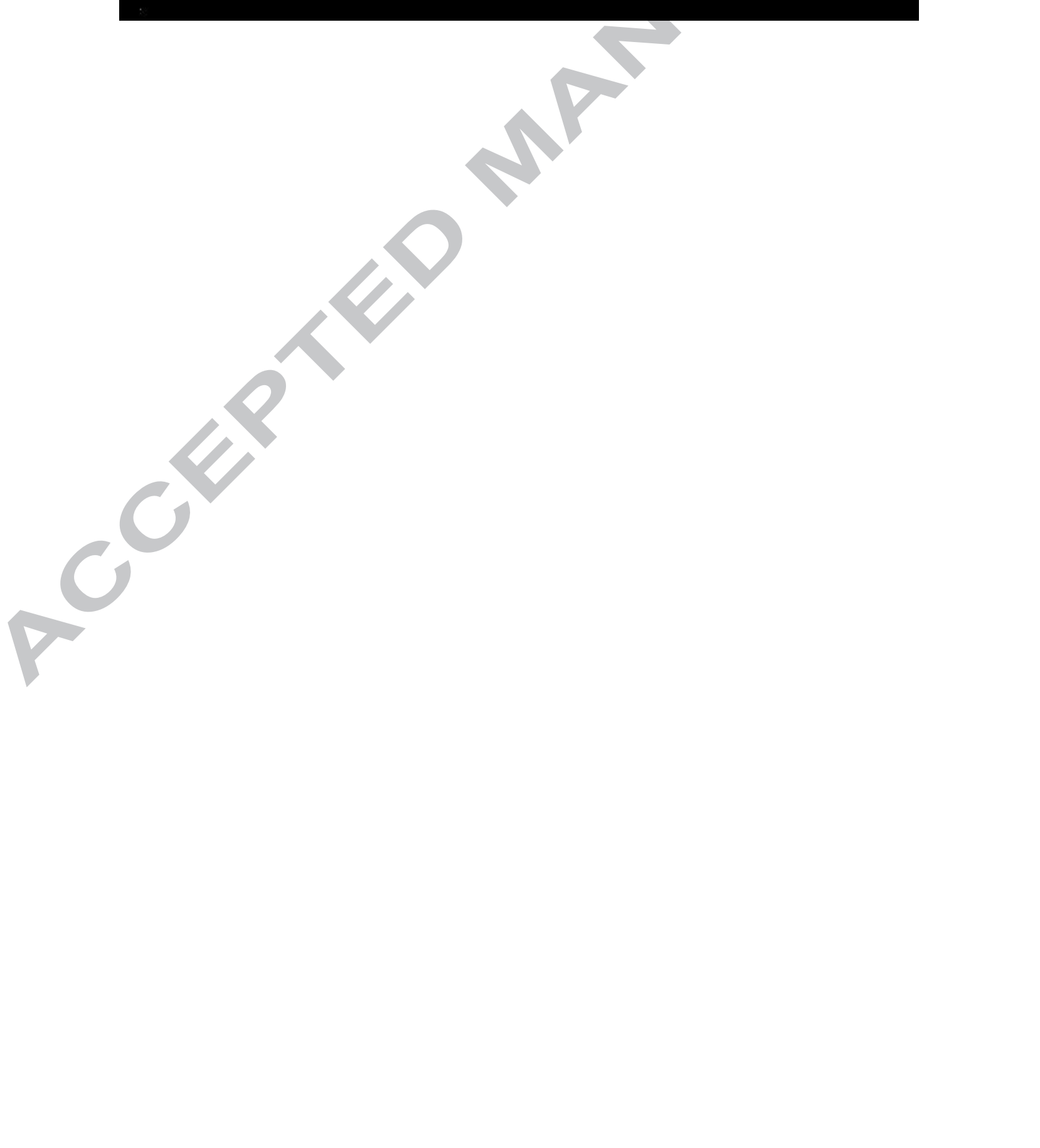

\section{ACCEPTED MANUSCRIPT}

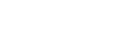




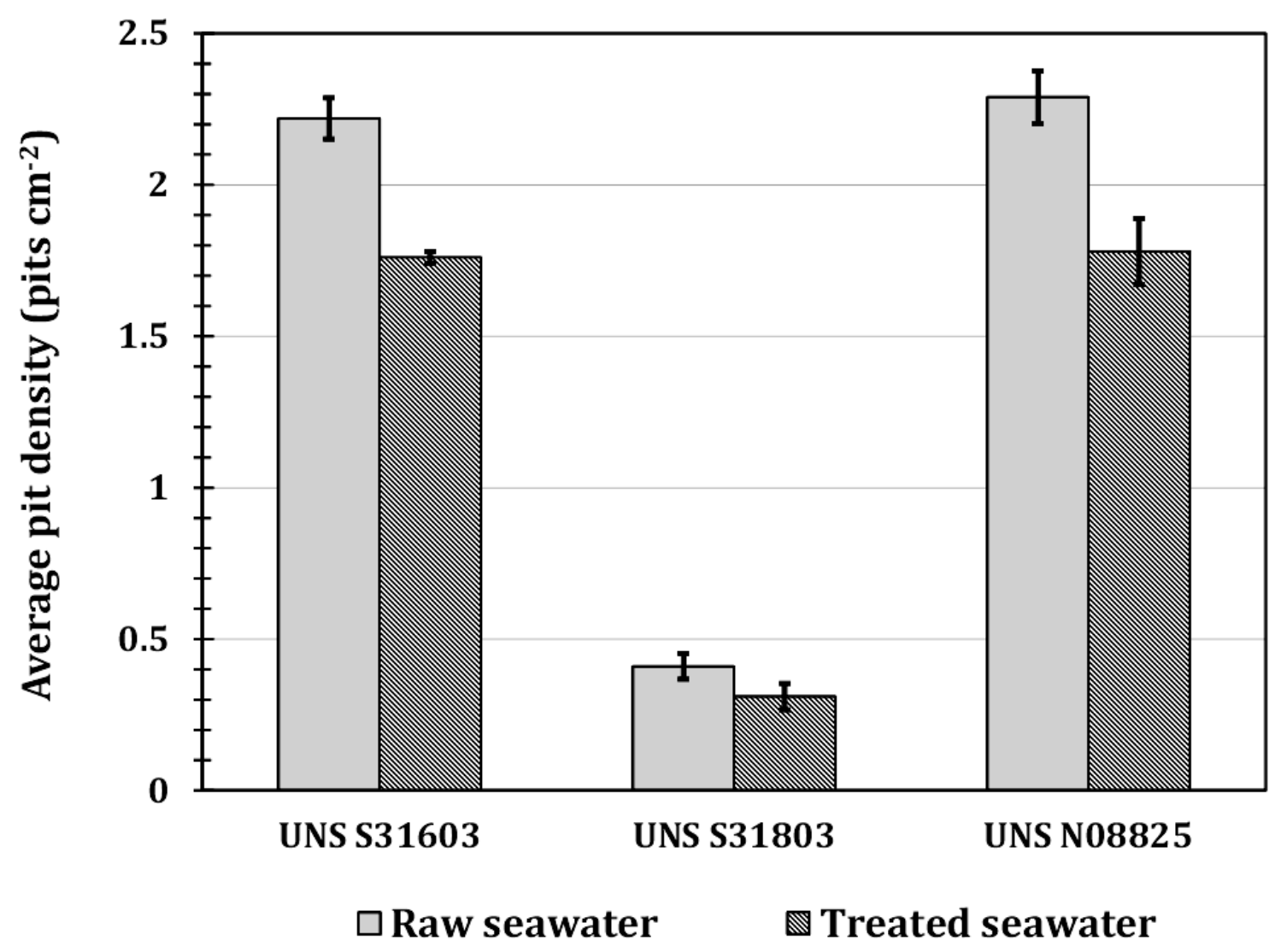




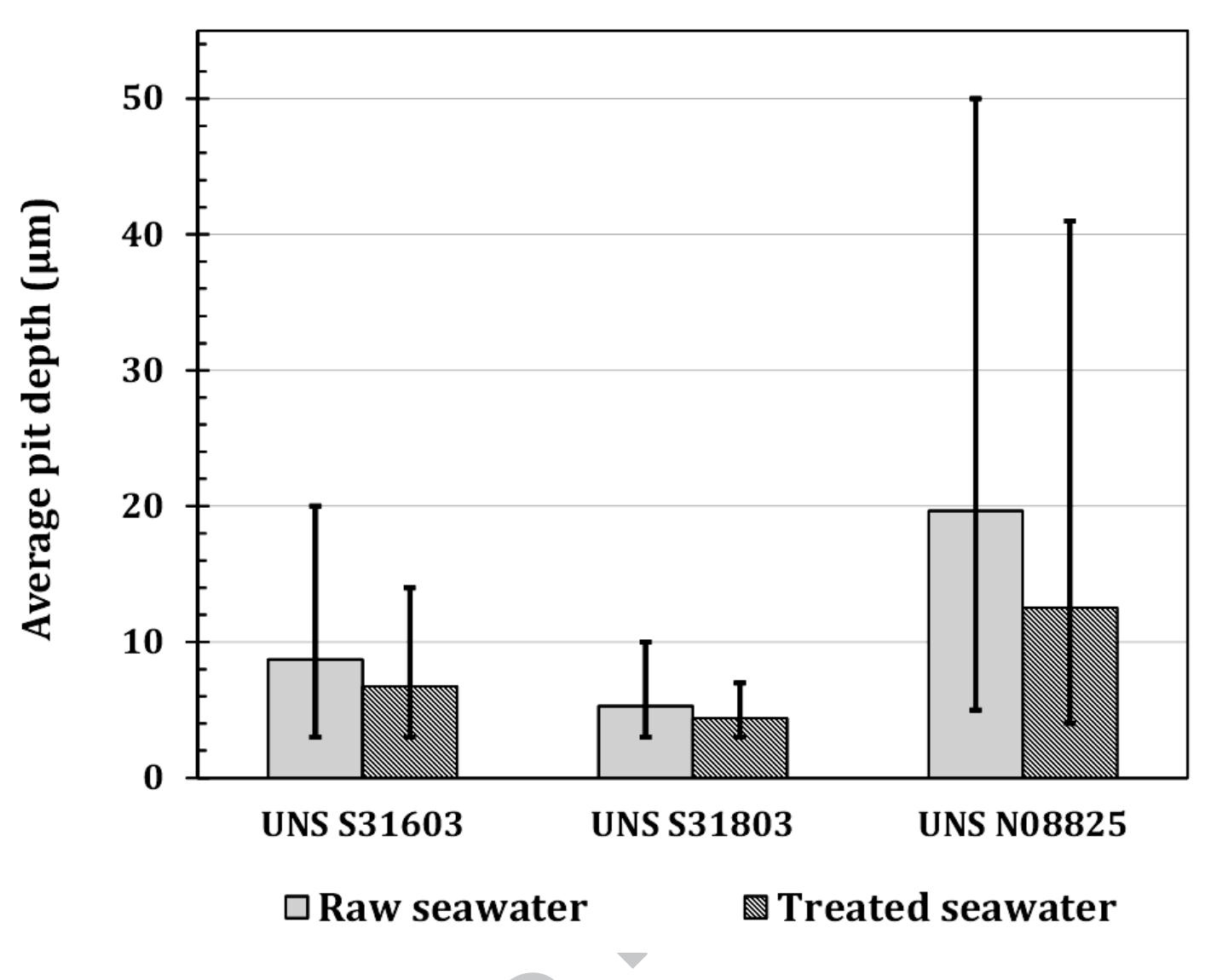

\section{ACCEPTED MANUSCRIPT}




\section{ACCEPTED MANUSCRIPT}

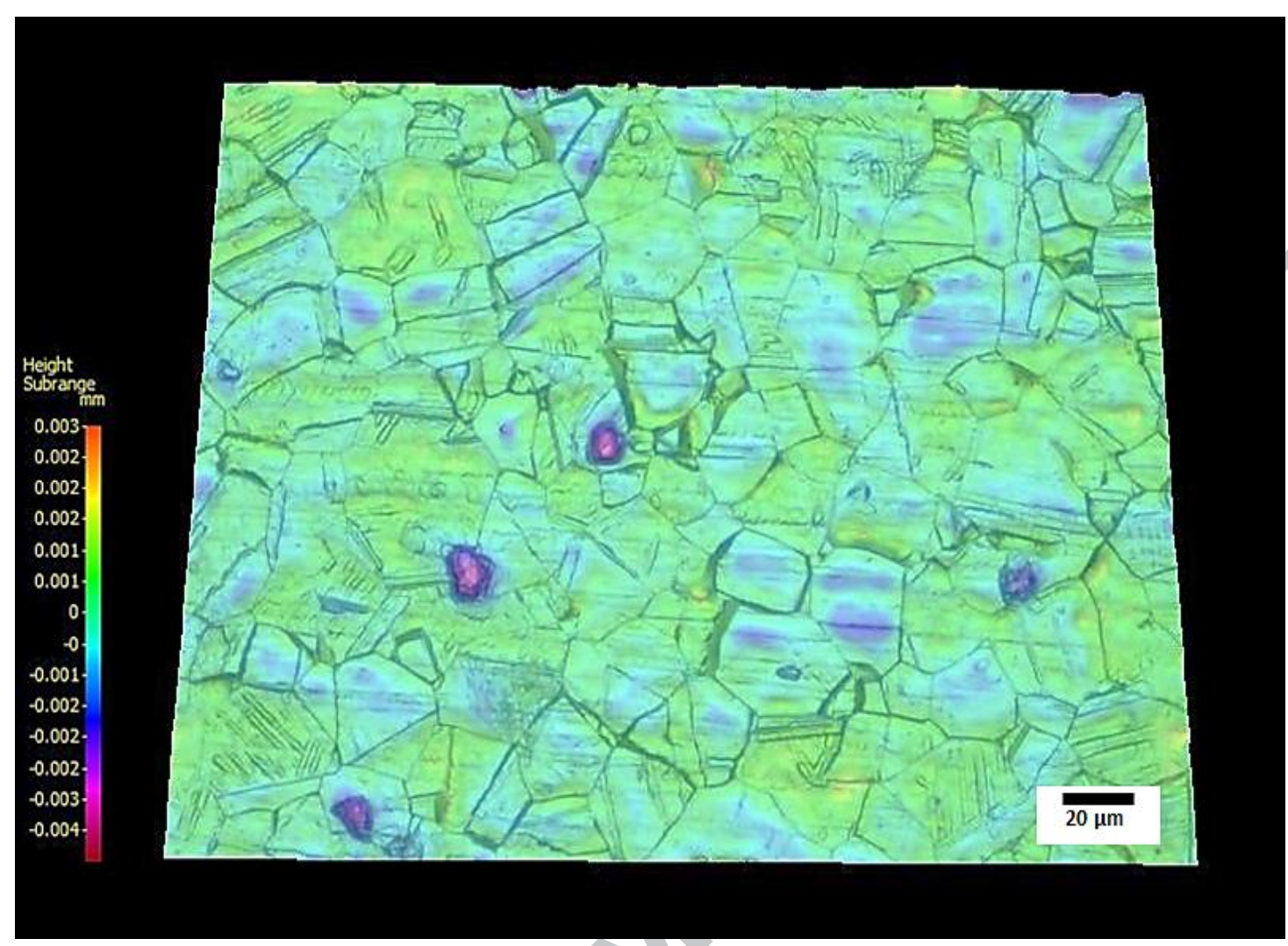

Figure 6 (color) 


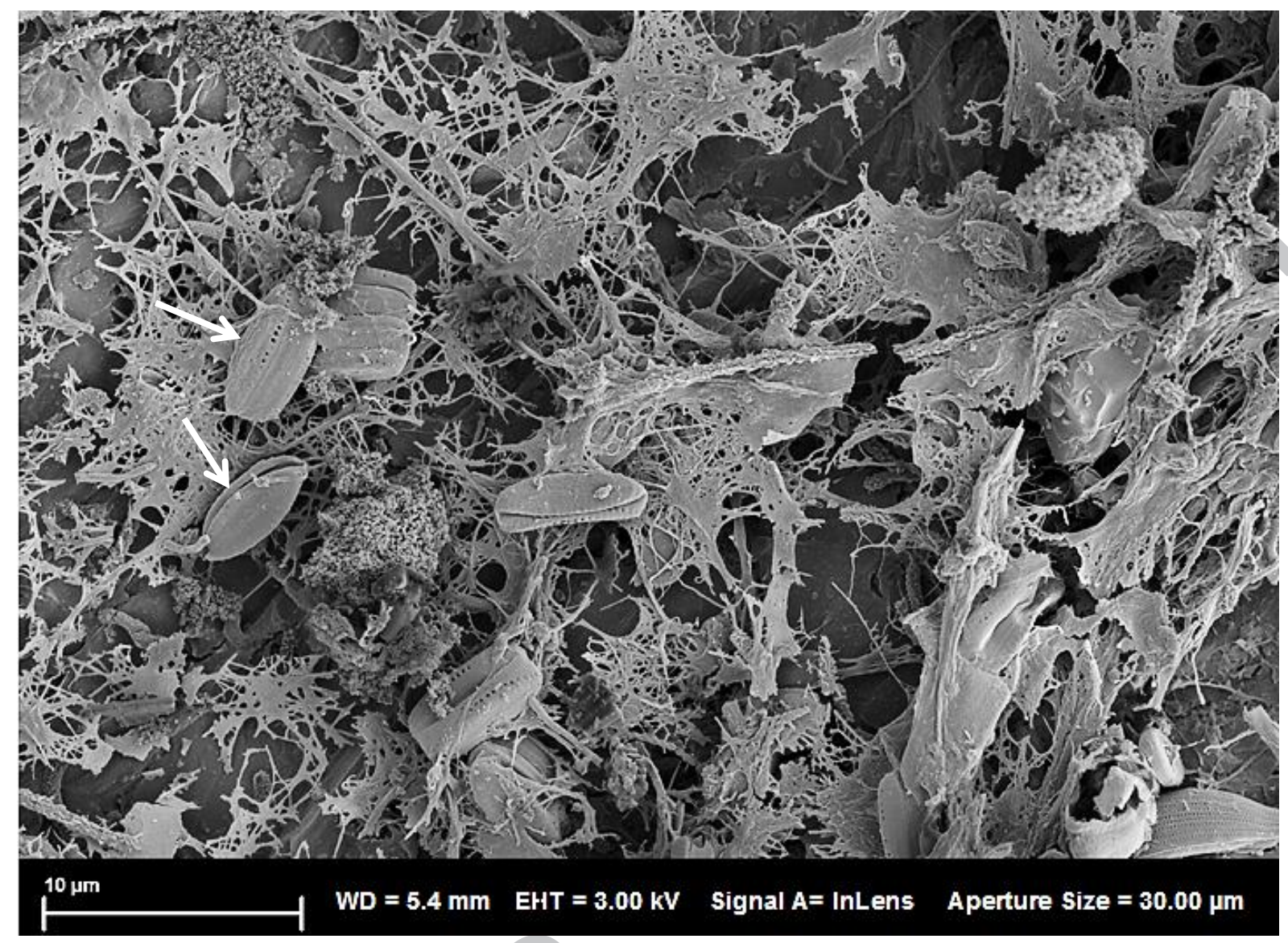

Figure $7 . a$ 


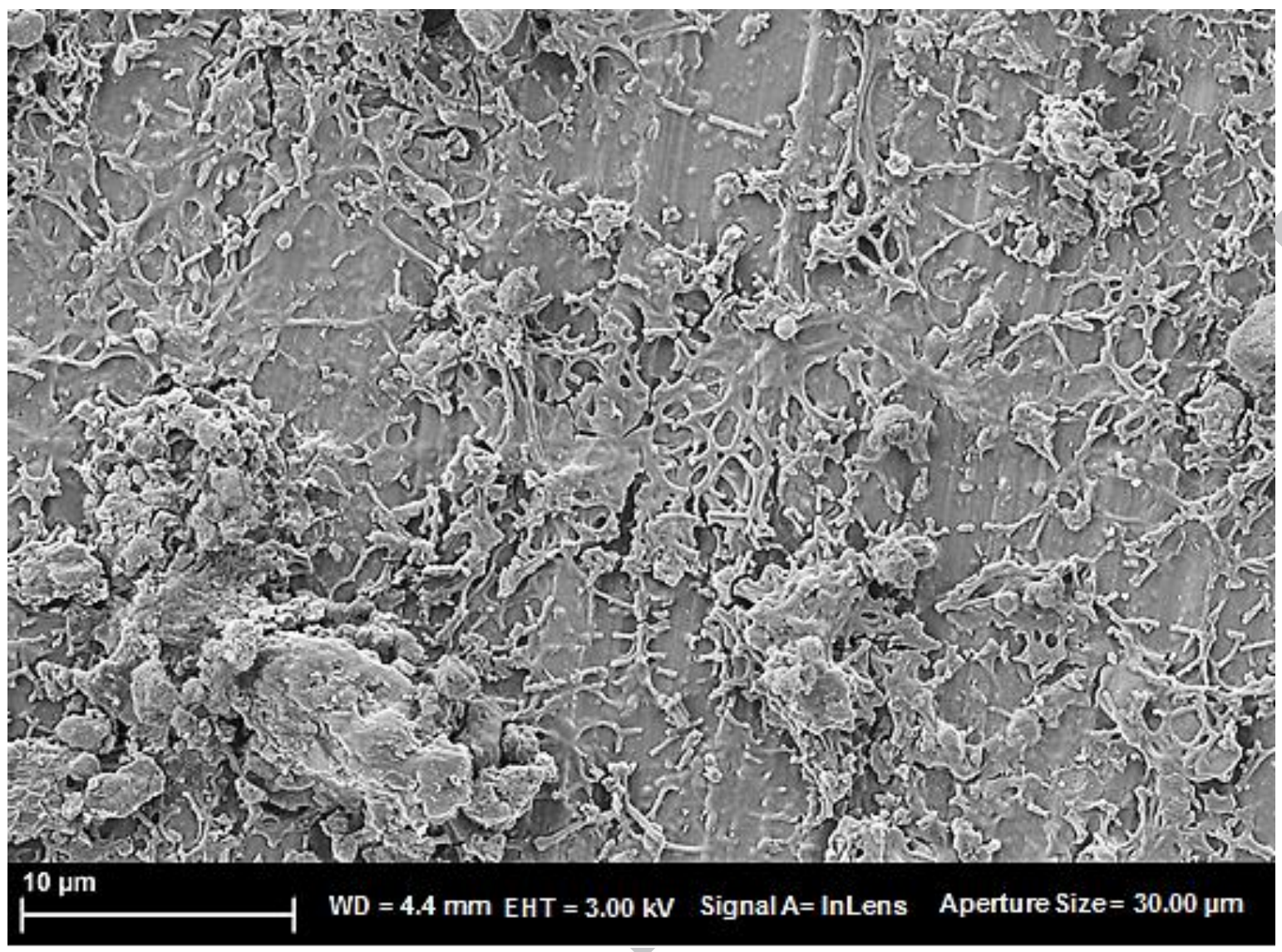




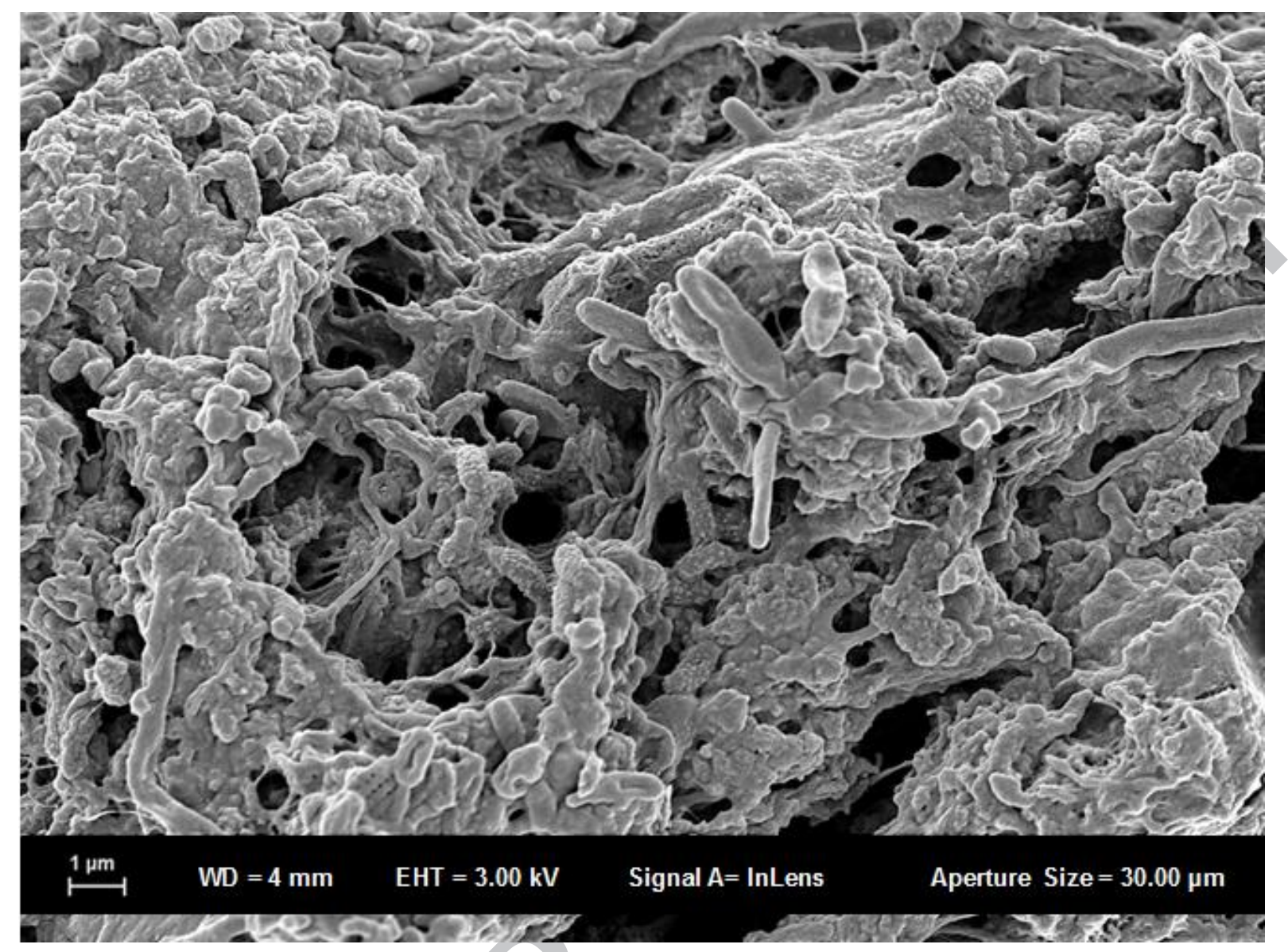

Figure 7.c

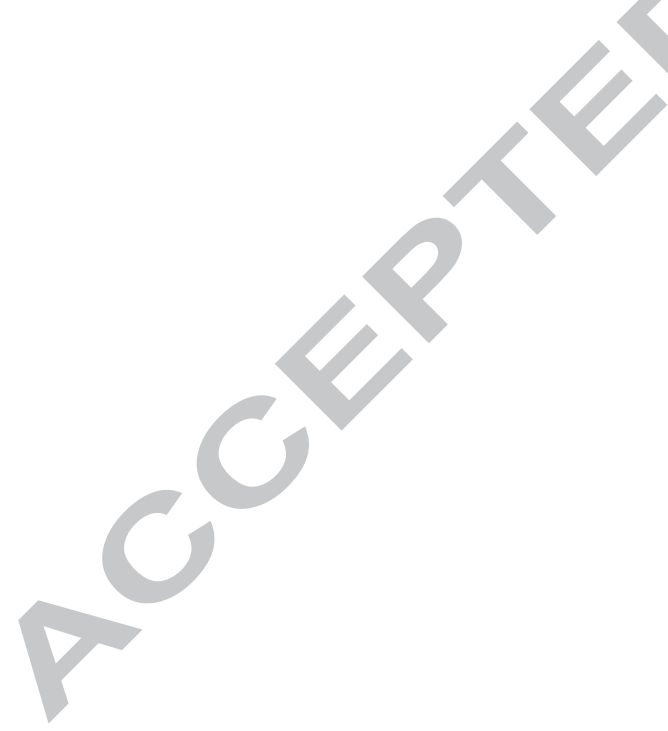




\section{ACCEPTED MANUSCRIPT}

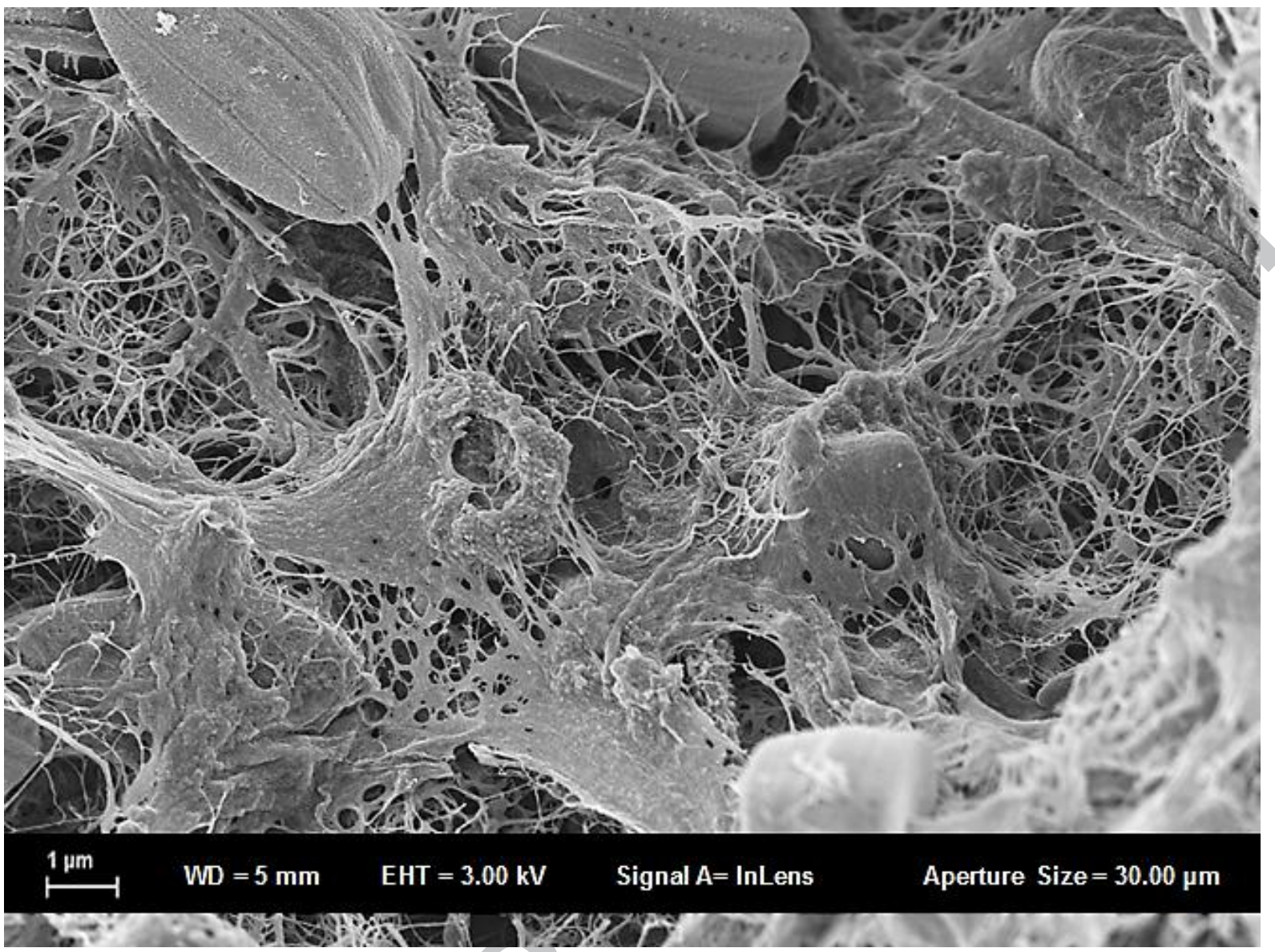


Figure 7.e.

ACCEPTED MANUSCRIPT
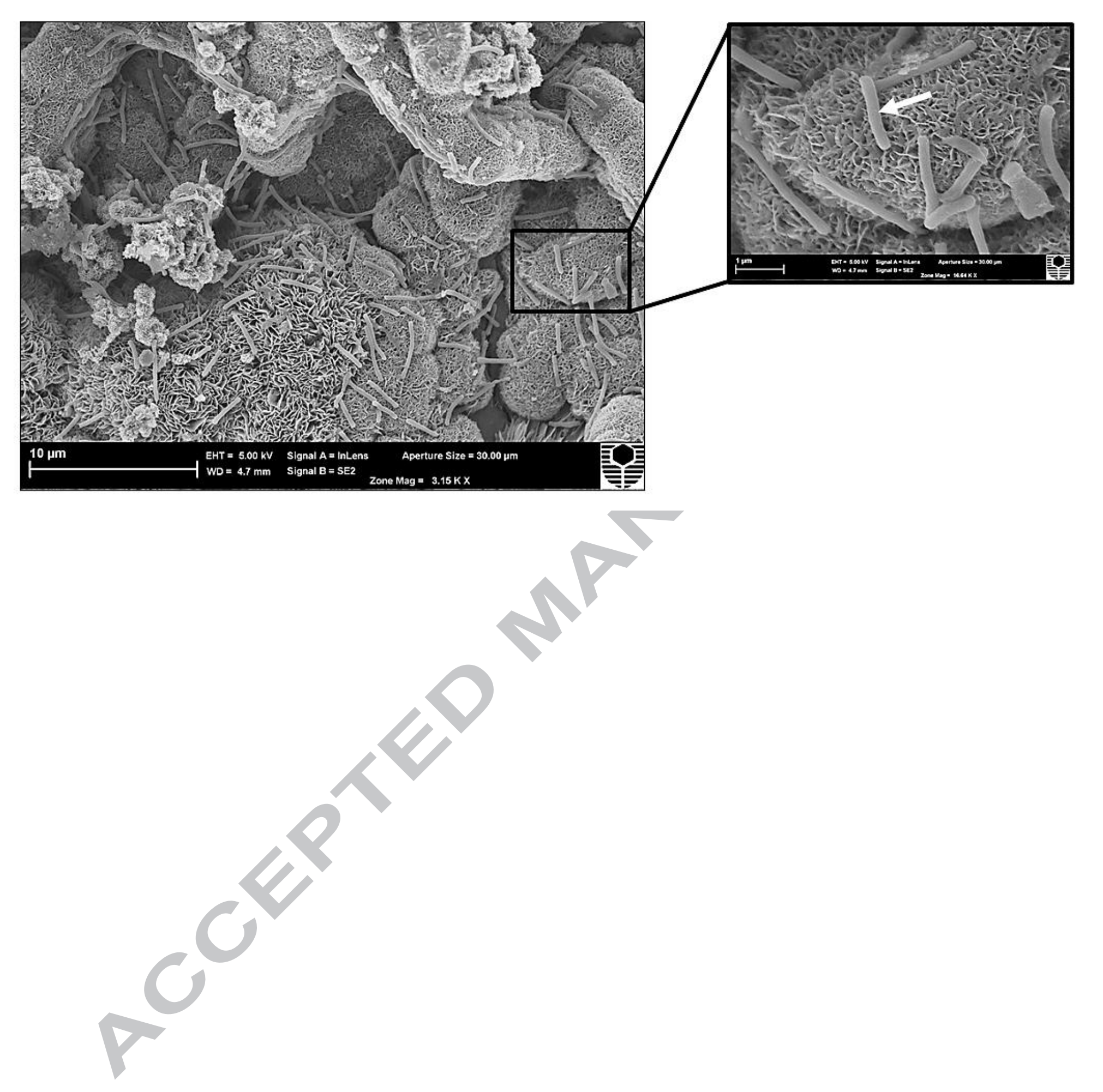

$\sqrt{2}$

.

.
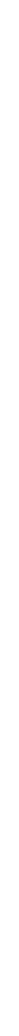


\section{Figure 8}

\section{ACCEPTED MANUSCRIPT}

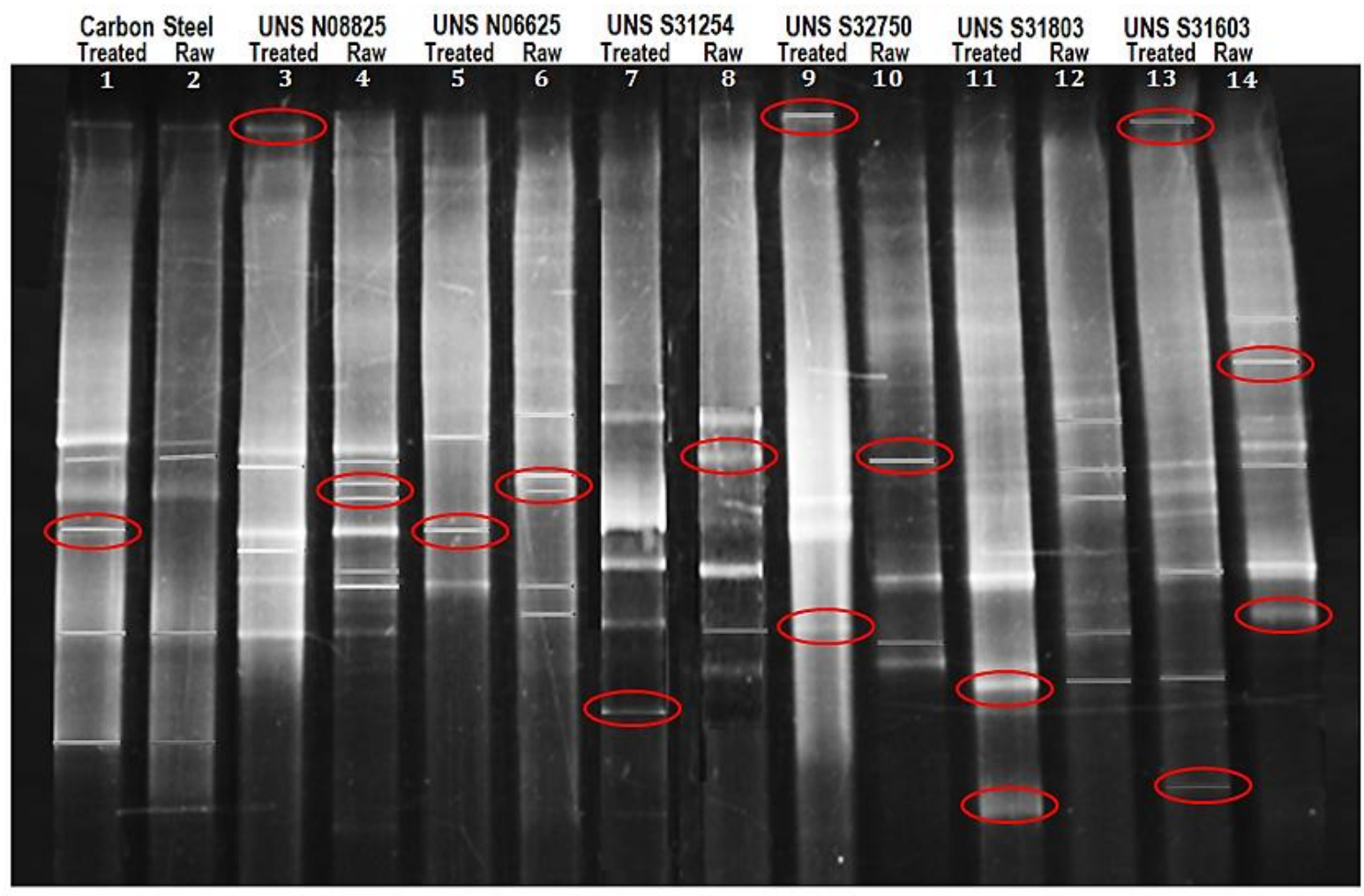

